\title{
THE NEOPROTEROZOIC ISLAND-ARC ASSOCIATION OF THE MUKODEK GOLD-ORE FIELD, NORTHERN BAIKAL AREA
}

\author{
V. A. Vanin, D. P. Gladkochub, T. V. Donskaya \\ Institute of the Earth's Crust of SB RAS, Irkutsk, Russia
}

\begin{abstract}
Metamorphosed volcanic rocks of the Ushmukan suite were studied in the Mukodek gold-ore field located in the Baikal-Muya belt in the Northern Baikal area, Russia. The Ushmukan suite shows interleaving of ortoschists which compositions are widely variable. Basalt-andesite-dacite series of normal alkalinity are the substrate of the studied metavolcanic rocks. Based on the set of geochemical characteristics, it is concluded that the rocks were formed in suprasubduction geodynamic conditions corresponding to a mature island arc. The proximity of the geological locations and the similarity of the geochemical characteristics of the volcanic rocks of the Ushmukan suite and rocks of the Kelyan suite (Neoproterozoic, $823 \mathrm{Ma}$ ), which have similar compositions, give grounds to consider these two rock suites as age peers. Specific features of gold distribution through the Mukodek gold-ore field are analyzed. Industrial gold contents are recorded only in berezitelistvenite metasomatic rocks of the gold-quartz-sulfide formation which were formed on metavolcanic rocks of the Ushmukan suite. It is concluded that the volcanic rocks, which are specific of the island-arc setting, could be a source of gold for deposits in the Mukodek gold-ore field.
\end{abstract}

Key words: Neoproterozoic, volcanic rocks, island arc, Baikal-Muya belt, Ushmukan suite, metasomatic rocks, gold-quartzsulfide formation, Mukodek gold-ore field.

Recommended by A.V. Ivanov

Citation: Vanin V.A., Gladkochub D.P., Donskaya T.V. 2014. The Neoproterozoic island-arc association of the Mukodek gold-ore field, Northern Baikal area. Geodynamics \& Tectonophysics 5 (3), 743-762. doi:10.5800/GT2014-5-3-0152.

\section{НЕОПРОТЕРОЗОЙСКАЯ ОСТРОВОДУЖНАЯ АССОЦИАЦИЯ ЗОЛОТОРУДНОГО ПОЛЯ МУКОДЕК (СЕВЕРНОЕ ПРИБАЙКАЛЬЕ)}

\author{
В. А. Ванин, Д. П. Гладкочуб, Т. В. Донская \\ Институт земной коры СО РАН, Иркутск, Россия
}

Аннотация: Проведено изучение метаморфизованных вулканических пород ушмуканской свиты на площади золоторудного поля Мукодек Байкало-Муйского пояса (Северное Прибайкалье). Установлено, что разрез ушмуканской свиты в районе исследований характеризуется чередованием ортосланцев широкого спектра составов. Показано, что субстратом изученных метавулканитов являлись породы базальт-андезит-дацитовой серии нормальной щелочности. По комплексу геохимических характеристик сделан вывод о формировании этих пород в надсубдукционных геодинамических условиях, отвечающих развитой островной дуге. Близость геологического положения и геохимических 
характеристик вулканитов ушмуканской свиты и аналогичных по составу пород келянской свиты неопротерозоя (823 млн лет), развитых на прилегающих территориях БМП, позволяет рассматривать образования этих двух подразделений в качестве возрастных аналогов. Проанализированы особенности распространения золота на площади золоторудного поля Мукодек. Установлено, что промышленные содержания золота зафиксированы лишь в березитлиственитовых метасоматитах золото-кварц-сульфидной формации, образованных по метавулканитам ушмуканской свиты. Сделан вывод о том, что вулканиты, имеющие отчетливую островодужную специфику, могли явиться источником золота для рудных объектов золоторудного поля Мукодек.

Ключевые слова: неопротерозой, вулканиты, островная дуга, Байкало-Муйский пояс, ушмуканская свита, метасоматиты, золото-кварц-сульфидная формация, золоторудное поле Мукодек.

\section{1. ВВЕДЕНИЕ}

Вторая половина XX в. стала временем коренного пересмотра взглядов о возрасте и геодинамической позиции целого ряда структур, входящих в состав складчатых областей Земли, в том числе ЦентральноАзиатского складчатого пояса (ЦАСП). Начало этому процессу в России положила статья А.В. Пейве [Peive, 1969], в которой, вслед за зарубежными коллегами, было показано, что в пределах внутриконтинентальных (в настоящее время) областей консолидированной литосферы могут сохраняться фрагменты океанической коры геологического прошлого. В начале 80-х годов прошлого столетия были опубликованы первые работы [Dobretsov, 1983; Dobretsov et al., 1985], объясняющие природу ряда геологических комплексов Северного Прибайкалья в рамках концепции литосферных плит. В последующем коренной пересмотр традиционных взглядов на геологию и тектонику ЦАСП коснулся и территории Восточно-Саянского сегмента этого пояса (см. обзор в [Belichenko et al., 1988; Dobretsov et al., 1989]). Эти, по сути пионерные, исследования проводились научным коллективом под руководством академика Н.Л. Добрецова. Среди наиболее активных участников этого научного коллектива могут быть упомянуты такие известные ученые-геологи, как Е.В. Скляров, Э.Г. Конников, А.С. Гибшер, А.Э. Изох, M.M. Буслов, Е.В. Хаин и другие. Синтез новых результатов, полученных по Северо-Байкальскому и Восточно-Саянскому сегментам ЦАСП, был представлен в фундаментальной работе «Тектоника литосферных плит территории СССР»[Zonenshain et al., 1990]. Таким образом, к началу 90-х годов прошлого века в научную литературу и в практику геологических исследований вошло понятие «Байкало-Муйский офиолитовый пояс», в пределах которого в последующем, кроме собственно базит-ультрабазитовых комплексов, априори признаваемых «офиолитовыми», были выделены вулканические ассоциации островодужной природы (келянская свита) [Konnikov et al., 1994].

Детальные работы, проведенные рядом исследовательских групп на территории Северного Прибайкалья, показали, что на площади Байкало-Муйского офи- олитового пояса, кроме собственно офиолитовых и островодужных комплексов, присутствуют образования, сформированные в совершенно различных геодинамических обстановках (см. обзор в [Tsygankov, 2005; Rytsk et al., 2007]), поэтому в настоящее время фрагмент ЦАСП, располагающийся между пассивной окраиной Сибирского кратона и Баргузинским микроконтинентом, рассматривается в качестве БайкалоМуйского пояса (БМП).

Предметом изучения, результаты которого представлены в данной статье, стали позднерифейские вулканические образования ушмуканской свиты западной части БМП, для которых был выполнен комплекс геологических, петрографических и геохимических исследований.

\section{2. ГЕОЛОГО-ПЕТРОГРАФИЧЕСКАЯ ХАРАКТЕРИСТИКА ПОРОД УШМУКАНСКОЙ СВИТЫ}

На территории Байкало-Муйского пояса в 1962 г. было выделено золоторудное проявление Мукодек при заверке магнитной аномалии, обнаруженной Монюканской партией геологосъемочной экспедиции ИГУ в процессе ГСР-50 [Artemiev, Tsypukov, 1963]. При дальнейших поисково-оценочных работах оно было переведено в ранг Мукодекского золоторудного поля, ставшего составной частью Северо-Байкальского золоторудного района. Согласно современной трактовке террейновой структуры Северного Прибайкалья [Rytsk et al., 2007], золоторудное поле Мукодек принадлежит Янской зоне Байкало-Муйского пояса ЦАСП, располагающейся вблизи южной границы Олокитской зоны (рис. 1).

В строении золоторудного поля участвуют позднерифейские породы осадочно-вулканогенной ушмуканской свиты, габбро-плагиограниты муйского комплекса, габбро таллаинского комплекса и раннепалеозойские гранитоиды конкудеро-мамаканского комплекса (рис. 2). Стоит отметить, что все породы, кроме гранитоидов конкудеро-мамаканского комплекса, испытали метаморфизм зеленосланцевой фации.

Основание золоторудного поля представлено оса- 


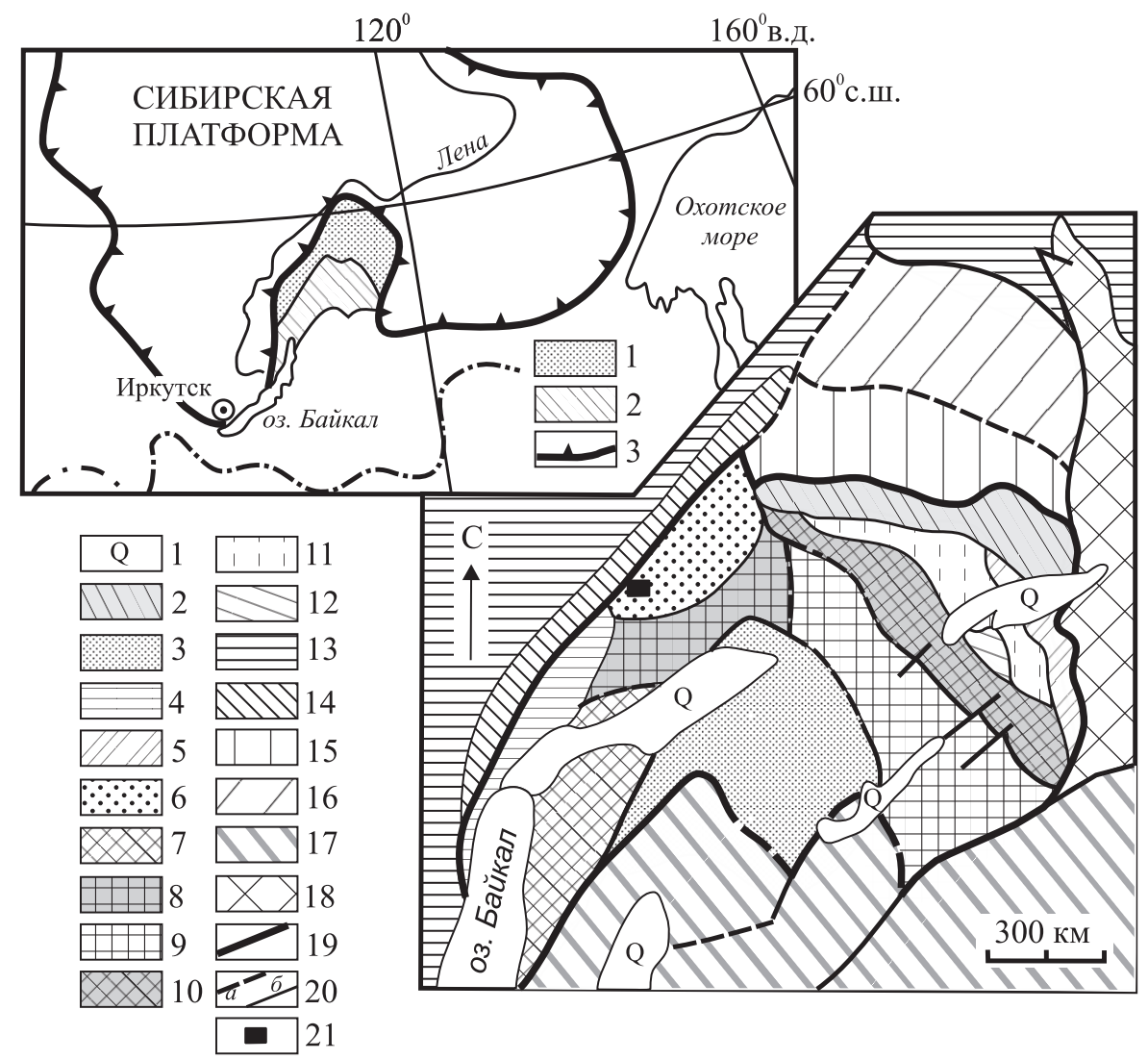

Рис. 1. Схема тектонических зон, блоков и террейнов Байкальской складчатой области (модифицировано по [Rytsk et al., 2007]).

1 - четвертичные впадины; 2-12 - Байкало-Муйский складчатый пояс: 2 - Каралон-Мамаканская зона, 3 - Катеро-Уакитская зона, 4 Кичерская зона, 5 - Парам-Шаманская зона, 6 - Янская зона, Анамакит-Муйская зона и ее подзоны: 7 - Светлинская, 8 - Угдокитская, 9 - Бамбуйско-Олиндинская, 10 - Келяно-Иракиндинская, 11 - Муйская, 12 - Киндиканский блок Муйской подзоны; 13-16 - БайкалоПатомский складчатый пояс: 13 - Кутимская, Мамская, Патомская зоны, 14 - Олокитская зона, 15 - Делюн-Уранская зона, 16 - Бодайбинская зона; 17 - Баргузино-Витимский супертеррейн; 18 - Алдано-Становой щит; 19 - тектонические границы Байкало-Муйского пояса; 20 - граничные разломы: а - предполагаемые, б - установленные; 21 - рудное поле Мукодек. На врезке показано положение Байкальской складчатой области. 1 - внешний Байкало-Патомский складчатый пояс; 2 - внутренний Байкало-Муйский складчатый пояс; 3 - тектонические границы Сибирской платформы.

Fig. 1. The scheme of tectonic zones, blocks and terrains of the Baikal folded area (modified from [Rytsk et al., 2007]).

1 - Quaternary depressions; 2-12 - Baikal-Muya folded belt: 2 - Karalon-Mamakan zone, 3 - Katero-Uakit zone, 4 - Kichera zone, 5 - ParamShaman zone, 6 - Yan zone, Anamakit-Muya zone and its subzones: 7 - Svetlinskaya, 8 - Ugdokit, 9 - Bambuy-Olinda, 10 - Kelyano-Irakinda, 11 - Muya, 12 - Kindikan block of Muya subzone; 13-16 - Baikal-Patom folded belt: 13 - Kutim, Mama, Patom zones, 14 - Olokit zone, 15 - Delyun-Uran zone, 16 - Bodaibo zone; 17 -- Barguzin-Vitim superterrain; 18 - Aldan-Stanovoi shield; 19 - tectonic boundaries of the Baikal-Muya folded belt; 20 - boundary faults: a - supposed, 6 - confirmed; 21 - Mukodek ore field. The inset shows the position of the Baikal folded area. 1 - external Baikal-Patom folded belt; 2 - internal Baikal-Muya folded belt; 3 - tectonic boundaries of the Siberian platform.

дочно-вулканогенными породами ушмуканской свиты. Именно с ней в Мукодекском рудном поле связаны все промышленные запасы золота. Ушмуканская свита выделена при ГДП-50 [Rozhok, 1995] и является аналогом наиболее известной келянской свиты. По последним данным возраст островодужной келянской свиты

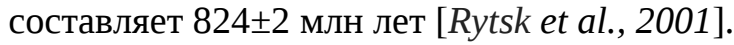

Разрез ушмуканской свиты в приустьевой зоне рек Левая и Правая Мама характеризуется чередованием кварц-амфибол-эпидотовых, хлорит-амфибол-кварцэпидотовых, хлорит-серицит-кварцевых и мусковитэпидот-кварцевых ортосланцев. Минеральный состав ортосланцев обусловлен различным сочетанием и процентным соотношением почти одних и тех же минералов: серицита, кварца, хлорита, обыкновенной роговой обманки и др.

Кварц-амфибол-эпидотовые ортосланцы имеют ориентированную и реликтовую-трахитоидную текстуру. Ориентированная текстура выражается в субпараллельном расположении призм измененного плагиоклаза и амфибола. Структура их гранонематобластовая, псевдоморфная, часто с замещениями. Главные минералы представлены зеленой роговой обманкой ( 30 \%), минералами группы эпидота ( 35 \%). Второ- 
$111^{\circ} 57^{\prime}$ в.д.

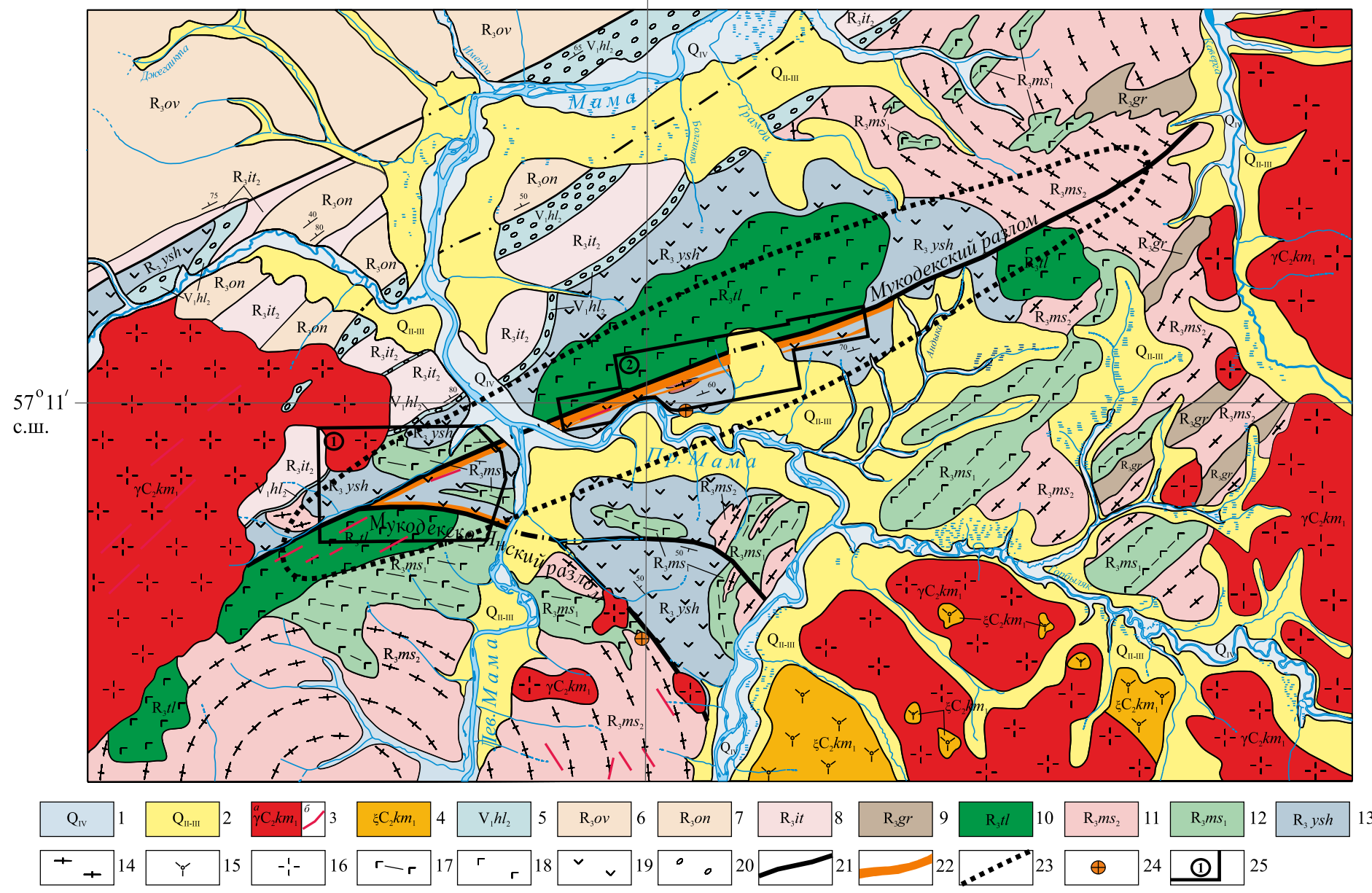

\section{Рис. 2. Обзорная геологическая карта золоторудного поля Мукодек.}

1 - современные валунно-галечные и песчаные аллювиальные отложения русел и пойм; 2 - средне- и верхнечетвертичные отложения, объединенные. Моренные глинисто-валунные, флювиогляциальные песчано-галечниково-валунные и аллювиальные отложения; 3-4 Конкудеро-мамаканский комплекс: 3 - амфиболовые, биотит-амфиболовые и биотитовые граниты (ү), 4 - среднезернистые сиениты (६); 5 - Холоднинская свита. Конгломераты, гравелиты, песчаники; 6 - Овгольская свита. Метаморфизованные песчаники, известковистые и гравелистые песчаники, гравелиты, алевролитовые и филлитовидные сланцы; 7 - Ондокская свита. Ритмичное переслаивание сланцев кварц-серицитовых, в том числе углеродсодержащих, и метапесчаников кварцевых, аркозовых, известковистых, углеродсодержащих, гравелистых; 8 - Итыкитская свита, верхняя подсвита. Переслаивание алевросланцев, метапесчаников, метагравелитов, сланцев по вулканогенным породам, горизонты кристаллических известняков; 9 - Горбылякская свита. Алевролиты, алевропесчанники, песчаники, редко гравелистые; 10 - таллаинский комплекс. Габбро, габбро-диабазы и ультрабазиты; 11-12 - муйский комплекс: 11 - вторая фаза, 12 - первая фаза; 13 - Ушмуканская свита. Вулканиты основного, кислого, среднего состава, ортосланцы; 14 - плагиогранитогнейсы; 15 - сиениты; 16 - граниты; 17 - полосчатое габбро; 18 - габбро; 19 - вулканиты; 20 - конгломераты; 21 - тектонические нарушения; 22 зоны золотоносных метасоматитов лиственит-березитовой формации слюдисто-карбонатно-кварцевого состава; 23 - примерные границы золоторудного поля Мукодек; 24 - пункты минерализации золота (до 1 г/т); 25 - границы участков детализации: 1 - Мукодек, 2 Правомамский.

Fig. 2. The geological survey map of the Mukodek gold-ore field.

1 - current boulder-pebble and sandy alluvial deposits of riverbeds and floodplains; 2 - Middle and Upper Quaternary sediments, combined. Moraine clay-boulder, fluvioglacial sand-pebble-boulder and alluvial deposits; 3-4 - Konkudero-Mamakan complex: 3 - amphibole, biotiteamphibole and biotite granite $(\gamma), 4$ - medium-grained syenite ( ()$; 5$ - Kholodninskaya suite. Conglomerates, gravelstones, sandstones; 6 - Ovgol suite. Metamorphosed sandstone, calcareous and gravelly sandstones, gravelstones, siltstone and phyllitic shists; 7 - Ondok suite. Rhythmic alternation of quartz-sericite schists, including carbonaceous and metasandstones (quartz, arkose, calcareous, carbonaceous, gravelly); 8 - Itykit suite, upper subsuite. Interbedded aleuritic schists, metasandstones, metagravelstones, schists on volcanic rocks, and crystalline limestone horizons; 9 Gorbylyak suite. Siltstone, aleuritic sandstones, sandstones (rarely gravelly); 10 - Tallainsky complex. Gabbro, gabbro-diabase and ultrabasic rocks; 11-12 - Muya complex: 11 - second phase, 12 - first phase; 13 - Ushmukan suite. Volcanic rocks (basic, acidic, medium composition), ortoschists; 14 - plagiogranitegneiss; 15 - syenite; 16 - granite; 17 - banded gabbro; 18 - gabbro; 19 - volcanic rocks; 20 - conglomerates; 21 tectonic faults; 22 - zones of gold-bearing metasomatic rocks of listvenite-berezite formation of mica-carbonate-quartz composition; 23 - assumed boundaries of the Mukodek gold-ore field; 24 - gold mineralization sites (up to $1 \mathrm{ppm}$ ); 25 - boundaries of sections studies in detail: 1 Mukodek, 2 - Mama (right bank). 
степенные минералы - плагиоклаз ( 10 \%), кварц ( 10 \%), серицит, актинолит. Из акцессорных минералов встречаются: ортит, апатит и сфен.

В породе плагиоклаз замещается серицитом, роговая обманка по краям зерен замещается светло-зеленым актинолитом, в центре зерен отмечаются мелкие кристаллики эпидота. Среди эпидот-цоизитовых минералов встречаются мелкие кристаллики апатита, зернистые скопления рудных минералов, иногда они образуют тонкую оторочку вокруг зеленой роговой обманки.

Хлорит-амфибол-кварц-эпидотовые ортосланцы имеют полосчато-сланцеватую текстуру и реликтовую порфировидную структуру. Главные минералы представлены кварцем ( 30 \%), минералами группы эпидота ( 40 \%), амфиболом ( 10\%), хлоритом ( 10\%). Среди второстепенных минералов отмечаются плагиоклаз, окислы железа, лейкоксен, серицит. Акцессорные - апатит, сфен, рудные минералы.

В породе зерна реликтового плагиоклаза слегка обдавлены и растянуты по направлению сланцеватости и густо серицитизированы, эпидотизированы, иногда обрамляются каймой из микрогранобластового кварца. Основная масса породы состоит из кристаллически зернистого эпидота, образующего сплошные массы, прослои, иногда полные псевдоморфозы по плагиоклазу. Среди эпидотизированных минералов отмечаются линзы, прослои зеленой роговой обманки, гранобластового кварца.

Порода заметно обогащена рудными минералами, сфеном. Сфен образует в большинстве своем идиоморфные кристаллы ромбовидной, конвертообразной формы. Магнетит, титаномагнетит представлены зернистыми агрегатами, образующими скопления. Рудные минералы, в том числе и сфен, отмечены в ассоциации с реликтовым плагиоклазом либо присутствуют в кварцевом агрегате.

Карбонатизированные хлорит-серицит-кварцевые ортосланцы имеют очково-сланцеватую, плойчатую текстуру. Структура - реликтовая, призматически зернистая, лепидогетерогранобластовая, пойкилобластовая. Главные минералы представлены кварцем ( 40 \%), серицитом ( 15 \%), хлоритом ( 15 \%), кальцитом ( 20 \%). Второстепенные минералы - плагиоклаз, лейкоксен, окислы железа. Среди акцессорных минералов отмечаются сфен, апатит и циркон.

В породе сохранились довольно крупные кристаллы плагиоклаза. Они обдавлены, развальцованы, разлинзованы и ориентированы по направлению сланцеватости. Основная масса породы состоит из гранобластового кварца, параллельно ориентированных пластинок хлорита и серицита. Под влиянием сжатия слюдистые минералы собраны в тонкие складочки. Вдоль плоскостей сланцеватости отмечается внедрение жилковидно-линзовидных обособлений крупнозернистого кальцита, замещающего основную массу породы. Иногда зерна кальцита переполнены мик- ровключениями кварца. Тонкозернистые рудные минералы, преимущественно титанистой группы, ассоциируют со слюдами. Отмечаются бластические новообразования альбита среди гранобластового кварца.

Мусковит-эпидот-кварцевые ортосланцы обладают очково-сланцеватой, полосчатой текстурой. Структура - порфиробластовая, лепидогетерогранобластовая. Среди главных минералов присутствуют: минералы группы эпидота ( 25 \%), мусковит ( 15 \%), кварц ( 44 \%). Второстепенные минералы представлены реликтовым плагиоклазом $\sim 10 \%$, хлоритом $~ 5 \%$, лейкоксеном, альбитом. Акцессорные минералы: циркон, апатит, сфен и ортит.

В составе основной массы доминирует гранобластовый кварц, микропластинчатый мусковит, ассоциирующий с тонколистоватым хлоритом. Эпидот образует в породе зернистые агрегаты, линзовидные обособления, короткие жилки. Зерна плагиоклаза обдавлены, слегка растянуты и ориентированы по направлению сланцеватости. По плагиоклазу развивается тонкочешуйчатый серицит, пелитистое вещество. Вкрапления рудных минералов ассоциируют с эпидотом, хлоритом.

\section{3. МЕТОДЫ ИССЛЕДОВАНИЯ}

Сорок шесть образцов вулканитов ушмуканской свиты были проанализированы на содержание петрогенных оксидов и элементов группы железа. Двенадцать из них проанализированы на содержание редких и редкоземельных элементов.

Определение основных петрогенных оксидов выполнено методом силикатного анализа в ИЗК СО РАН (аналитики Г.В. Бондарева, Т.В. Попова). Содержания $\mathrm{Co}, \mathrm{Ni}, \mathrm{Sc}, \mathrm{V}, \mathrm{Cr}$ определены методом спектрального анализа в ИЗК СО РАН (аналитики В.В. Щербань, А.В. Наумова). Определение содержаний редких и редкоземельных элементов было выполнено в ЦКП ИНЦ CO РАН на квадрупольном масс-спектрометре Agilent 7500 се ICP-MS (аналитик C.В. Пантеева) по методике [Panteeva et al., 2003]. Калибровка прибора осуществлялась по международным стандартам G-2, GSP-2, BHVO-1, DNC-1, JB-2, W-2. Ошибка определений редких и редкоземельных элементов методом ICP-MS coставляет не более 5 \%.

\section{4. ГЕОХИМИЧЕСКАЯ ХАРАКТЕРИСТИКА И ПЕТРОГЕНЕЗИС ОРТОСЛАНЦЕВ УШМУКАНСКОЙ СВИТЫ}

Исследованные породы ушмуканской свиты метаморфизованы, а также подвержены гидротермальнометасоматической переработке, что создает определенные трудности при их петрогеохимической классификации. В связи с этим для систематизации данных 
$a$

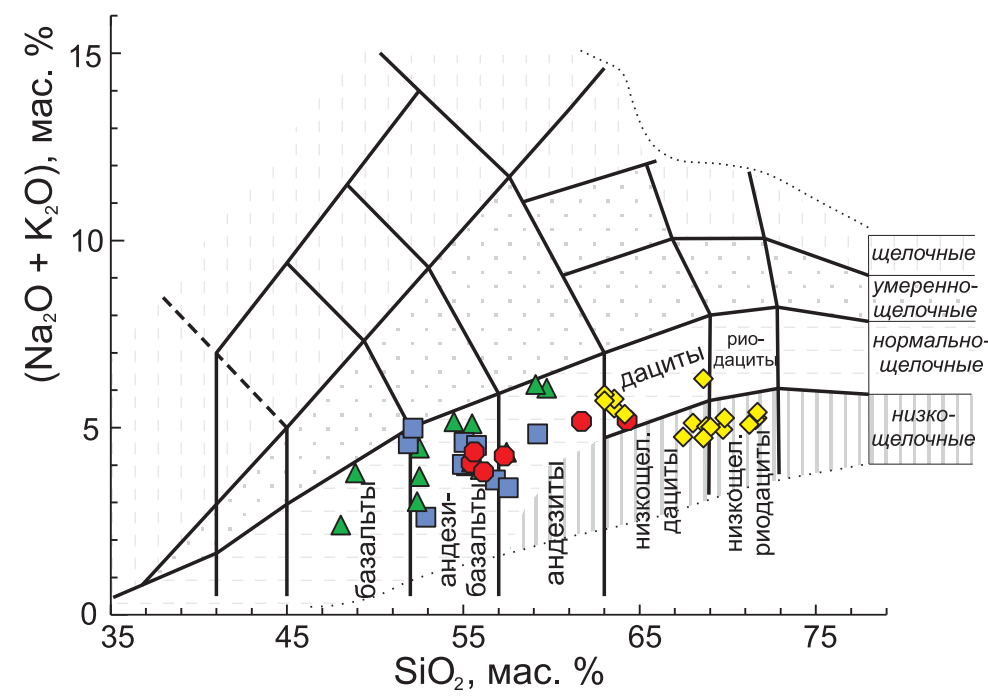

6

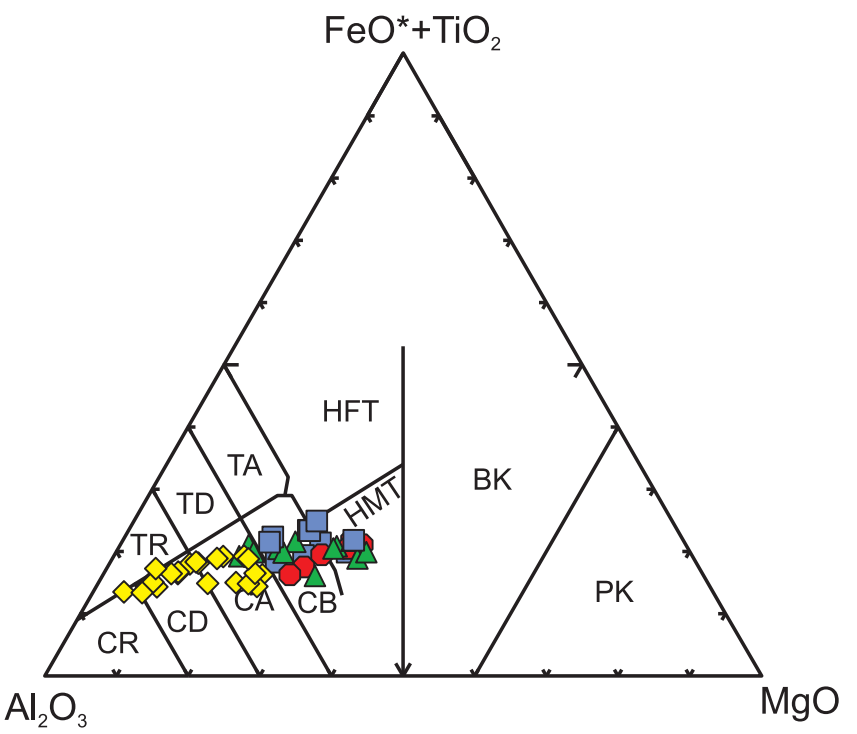

B

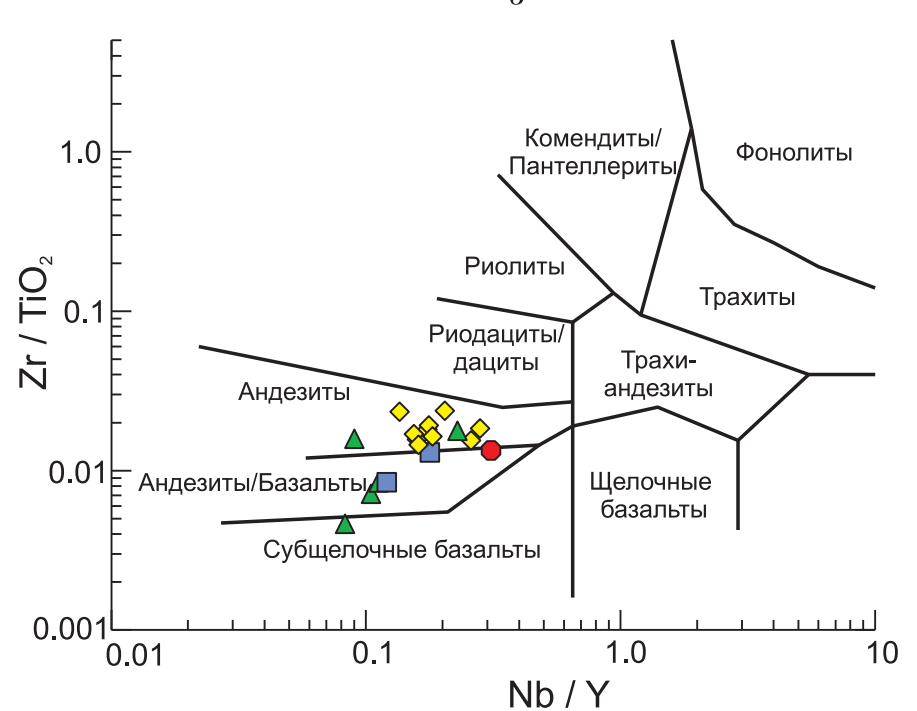

$\mathrm{Nb} / \mathrm{Y}$
Рис. 3. Классификационные диаграммы $\left(\mathrm{Na}_{2} \mathrm{O}+\right.$ $\left.+\mathrm{K}_{2} \mathrm{O}\right)-\mathrm{SiO}_{2}$ [Le Maitre, 1989], модифицированная [Petrographic Code..., 2009] (a); $\mathrm{Al}_{2} \mathrm{O}_{3}-\left(\mathrm{FeO}^{*}+\mathrm{TiO}_{2}\right)$ MgO [Jensen, 1976] (б); $\mathrm{Zr} / \mathrm{TiO}-\mathrm{Nb} / \mathrm{Y}$ [Winchester, Floyd, 1977] (в) для метаморфизованных вулканитов ушмуканской свиты.

1 - кварц-амфибол-эпидотовые ортосланцы; 2 - хлоритамфибол-кварц-эпидотовые ортосланцы; 3 - хлорит-серицит-кварцевые ортосланцы; 4 - мусковит-эпидот-кварцевые ортосланцы. (б) ВК - базальтовые коматииты, СА - известково-щелочные андезиты, СВ - известково-щелочные базальты, CD - известково-щелочные дациты, CR - известково-щелочные риолиты, PK - пикриты, HFT - высокожелезистые толеиты, НМТ - высокомагнезиальные толеиты, ТА толеитовые андезиты, TD - толеитовые дациты, TR - толеитовые риолиты.

Fig. 3. Classification diagrams $\left(\left(\mathrm{Na}_{2} \mathrm{O}+\mathrm{K}_{2} \mathrm{O}\right)-\mathrm{SiO}_{2}[\mathrm{Le}\right.$ Maitre, 1989], modified from [Petrographic Code..., 2009] (a); $\mathrm{Al}_{2} \mathrm{O}_{3}-\left(\mathrm{FeO}^{*}+\mathrm{TiO}_{2}\right)-\mathrm{MgO}$ [Jensen, 1976] (б); $\mathrm{Zr} / \mathrm{TiO}-\mathrm{Nb} / \mathrm{Y}$ [Winchester, Floyd, 1977] (в) for metamorphosed volcanic rocks of the Ushmukan suite.

Ortoschists: 1 - quartz-amphibole-epidote; 2 - chlorite-amphibole-quartz-epidote; 3 - chlorite-sericite-quartz; 4 - muscovite-epidote-quartz. (б) BK - basaltic komatiite, CA - calcalkalic andesite, CB - calc-alkalic basalt, CD - calc-alkalic dacite, CR - calc-alkalic rhyolite, PK - picrite, HFT - high-Fe tholeiite, HMT - high-Mg tholeiite, TA - tholeiitic andesite, TD - tholeiitic dacite, TR - tholeiitic rhyolite. 
Т а б л и ц а 1 . Содержание петрогенных оксидов и элементов группы железа в метаморфизованных вулканитах ушмуканской свиты

$\mathrm{T}$ a b l e 1. Contents of major oxides and iron-group elements in metamorphosed volcanic rocks of the Ushmukan suite

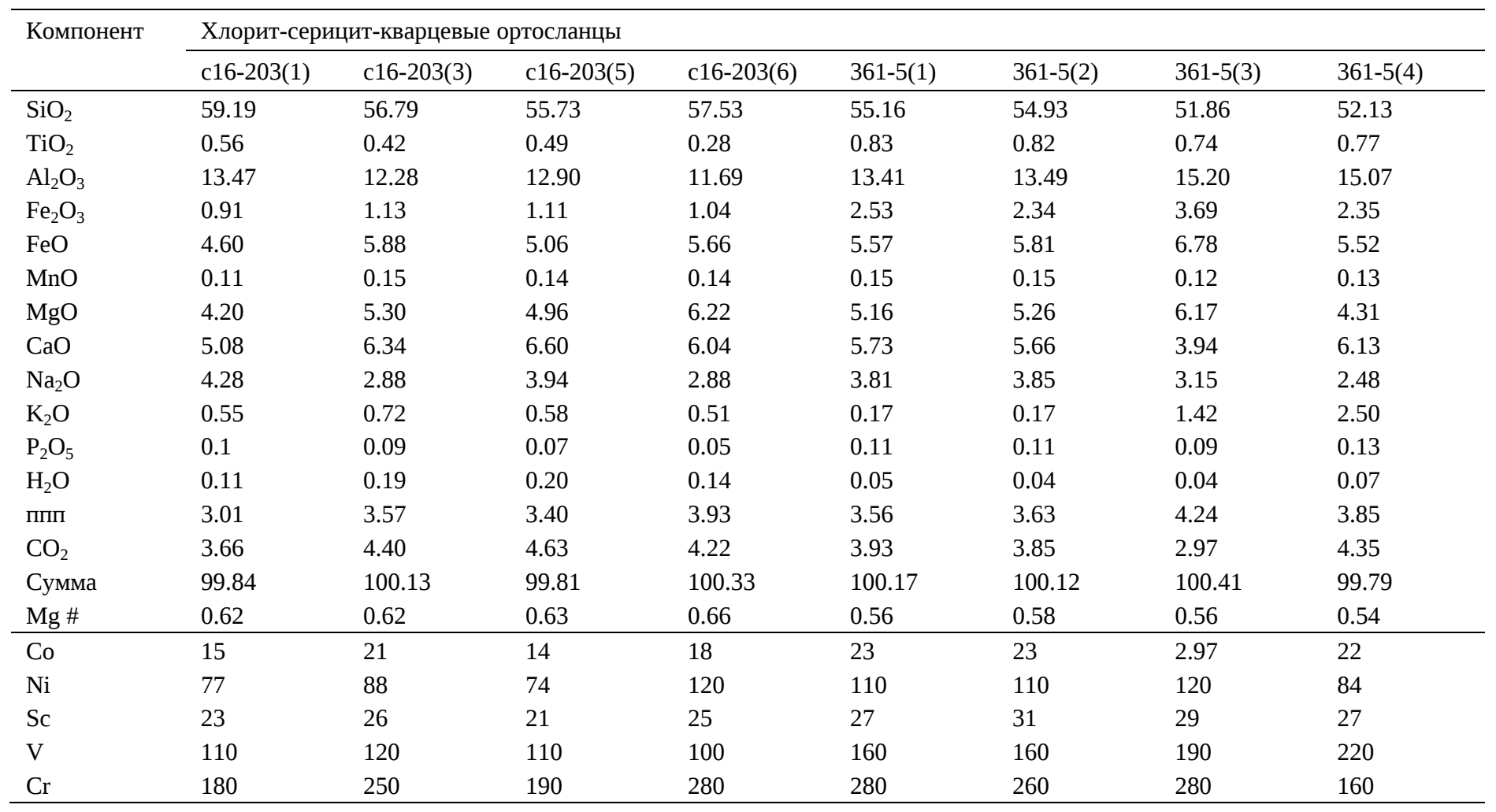

Продолжени и та блицы 1

Continuation of Table 1

\begin{tabular}{|c|c|c|c|c|c|c|c|c|}
\hline \multirow[t]{2}{*}{ Компонент } & \multicolumn{2}{|c|}{$\begin{array}{l}\text { Хлорит-серицит- } \\
\text { кварцевые ортосланцы }\end{array}$} & \multicolumn{6}{|c|}{ Кварц-амфибол-эпидотовые ортосланцы } \\
\hline & $361-5(5)$ & $361-5(6)$ & c18-97(1) & c18-97(2) & c18-97(3) & c18-97(4) & c18-97(5) & c18-97(6) \\
\hline $\mathrm{SiO}_{2}$ & 55.02 & 52.85 & 55.43 & 56.13 & 61.67 & 55.60 & 57.29 & 64.26 \\
\hline $\mathrm{TiO}_{2}$ & 0.62 & 0.38 & 0.39 & 0.50 & 0.29 & 0.32 & 0.27 & 0.23 \\
\hline $\mathrm{Al}_{2} \mathrm{O}_{3}$ & 13.64 & 12.85 & 13.20 & 12.90 & 13.65 & 13.35 & 13.95 & 13.35 \\
\hline $\mathrm{Fe}_{2} \mathrm{O}_{3}$ & 2.47 & 1.80 & 3.48 & 3.38 & 2.47 & 3.14 & 3.01 & 2.13 \\
\hline $\mathrm{MgO}$ & 3.83 & 7.1 & 7.79 & 7.02 & 5.37 & 7.11 & 6.16 & 4.76 \\
\hline $\mathrm{CaO}$ & 6.95 & 6.16 & 8.02 & 8.69 & 5.79 & 8.51 & 8.12 & 5.48 \\
\hline $\mathrm{Na}_{2} \mathrm{O}$ & 3.99 & 1.55 & 2.29 & 2.41 & 3.38 & 3.27 & 2.79 & 3.60 \\
\hline $\mathrm{K}_{2} \mathrm{O}$ & 0.61 & 1.06 & 1.76 & 1.41 & 1.78 & 1.08 & 1.45 & 1.59 \\
\hline $\mathrm{P}_{2} \mathrm{O}_{5}$ & 0.08 & 0.10 & 0.06 & 0.07 & 0.04 & 0.04 & 0.03 & 0.03 \\
\hline $\mathrm{Mg} \#$ & 0.55 & 0.64 & 0.66 & 0.65 & 0.66 & 0.64 & 0.64 & 0.66 \\
\hline Co & 17 & 28 & 34 & 28 & 27 & 32 & 0.22 & 28 \\
\hline $\mathrm{Ni}$ & 78 & 140 & 33 & 29 & 26 & 35 & 34 & 24 \\
\hline Sc & 31 & 35 & 32 & 27 & 32 & 29 & 27 & 23 \\
\hline $\mathrm{V}$ & 210 & 190 & 150 & 170 & 150 & 150 & 200 & 150 \\
\hline $\mathrm{Cr}$ & 240 & 390 & 400 & 440 & 490 & 560 & 590 & 540 \\
\hline
\end{tabular}


V.A. Vanin et al.: The Neoproterozoic island-arc association...

Продолжение та блицы 1

Continuation of Table 1

\begin{tabular}{|c|c|c|c|c|c|c|c|c|}
\hline \multirow[t]{2}{*}{ Компонент } & \multicolumn{8}{|c|}{ Хлорит-амфибол-кварц-эпидотовые ортосланцы } \\
\hline & $361-1(1)$ & $361-1(2)$ & $361-1(3)$ & $361-1(4)$ & $361-1(5)$ & $361-1(6)$ & $361-4(1)$ & $361-4(3)$ \\
\hline $\mathrm{SiO}_{2}$ & 52.50 & 52.50 & 59.71 & 55.48 & 59.08 & 54.45 & 55.93 & 52.36 \\
\hline $\mathrm{Al}_{2} \mathrm{O}_{3}$ & 17.10 & 16.20 & 16.10 & 16.05 & 15.80 & 15.90 & 13.80 & 14.45 \\
\hline $\mathrm{Fe}_{2} \mathrm{O}_{3}$ & 4.13 & 3.66 & 2.48 & 2.91 & 2.48 & 2.75 & 4.29 & 4.23 \\
\hline $\mathrm{FeO}$ & 4.04 & 5.11 & 4.12 & 4.82 & 4.50 & 4.90 & 4.22 & 5.42 \\
\hline $\mathrm{CaO}$ & 11.16 & 8.83 & 4.29 & 6.78 & 4.37 & 8.56 & 8.27 & 8.32 \\
\hline $\mathrm{Na}_{2} \mathrm{O}$ & 3.23 & 2.55 & 4.01 & 3.36 & 3.80 & 3.76 & 2.85 & 2.04 \\
\hline $\mathrm{K}_{2} \mathrm{O}$ & 0.46 & 1.90 & 2.04 & 1.74 & 2.35 & 1.39 & 1.03 & 0.98 \\
\hline $\mathrm{P}_{2} \mathrm{O}_{5}$ & 0.08 & 0.09 & 0.23 & 0.10 & 0.24 & 0.06 & 0.09 & 0.11 \\
\hline $\mathrm{H}_{2} \mathrm{O}$ & 0.11 & 0.03 & 0.03 & 0.03 & 0.03 & 0.01 & 0.08 & 0.01 \\
\hline $\mathrm{Mg} \#$ & 0.52 & 0.59 & 0.54 & 0.58 & 0.55 & 0.60 & 0.64 & 0.64 \\
\hline Co & 17 & 20 & 12 & 16 & 0.11 & 18 & 29 & 25 \\
\hline $\mathrm{Ni}$ & 130 & 130 & 46 & 91 & 40 & 120 & 96 & 250 \\
\hline Sc & 53 & 68 & 13 & 35 & 29 & 35 & 16 & 33 \\
\hline $\mathrm{V}$ & 300 & 390 & 89 & 230 & 170 & 200 & 190 & 220 \\
\hline $\mathrm{Cr}$ & 230 & 390 & 49 & 220 & 67 & 240 & 310 & 420 \\
\hline
\end{tabular}

Продолжение таблицы 1

Continuation of Table 1

\begin{tabular}{|c|c|c|c|c|c|c|c|c|}
\hline \multirow[t]{2}{*}{ Компонент } & \multicolumn{4}{|c|}{ Хлорит-амфибол-кварц-эпидотовые ортосланцы } & \multicolumn{4}{|c|}{ Мусковит-эпидот-кварцевые ортосланцы } \\
\hline & $361-4(5)$ & $361-4(6)$ & скк161-1 & скк161-2 & $441(1)$ & $441(2)$ & $441(3)$ & $441(4)$ \\
\hline $\mathrm{SiO}_{2}$ & 57.44 & 55.45 & 48.04 & 48.86 & 69.70 & 67.99 & 69.78 & 71.62 \\
\hline $\mathrm{Al}_{2} \mathrm{O}_{3}$ & 13.15 & 13.20 & 15.07 & 15.25 & 13.50 & 14.20 & 14.06 & 13.96 \\
\hline $\mathrm{Fe}_{2} \mathrm{O}_{3}$ & 3.17 & 3.24 & 3.67 & 1.48 & 2.08 & 2.20 & 1.81 & 1.87 \\
\hline $\mathrm{FeO}$ & 4.44 & 5.04 & 4.77 & 4.71 & 2.50 & 2.69 & 2.45 & 1.86 \\
\hline MgO & 7.57 & 8.05 & 7.23 & 6.59 & 1.75 & 2.05 & 1.63 & 1.09 \\
\hline $\mathrm{CaO}$ & 6.67 & 7.54 & 11.99 & 9.63 & 2.76 & 2.78 & 2.52 & 2.24 \\
\hline $\mathrm{Na}_{2} \mathrm{O}$ & 2.57 & 2.27 & 2.10 & 3.13 & 3.88 & 3.76 & 3.96 & 3.97 \\
\hline $\mathrm{K}_{2} \mathrm{O}$ & 1.77 & 1.81 & 0.30 & 0.66 & 1.07 & 1.36 & 1.29 & 1.28 \\
\hline $\mathrm{P}_{2} \mathrm{O}_{5}$ & 0.06 & 0.10 & 0.04 & 0.05 & 0.11 & 0.12 & 0.10 & 0.09 \\
\hline $\mathrm{H}_{2} \mathrm{O}$ & 0.01 & 0.01 & 0.04 & 0.05 & 0.11 & 0.15 & 0.13 & 0.12 \\
\hline $\mathrm{Mg} \#$ & 0.69 & 0.68 & 0.65 & 0.70 & 0.46 & 0.48 & 0.46 & 0.39 \\
\hline Co & 32 & 35 & 35 & 32 & 14 & 13 & 12 & 7.4 \\
\hline $\mathrm{Ni}$ & 170 & 170 & 67 & 74 & 37 & 21 & 24 & 8.3 \\
\hline Sc & 27 & 23 & 26 & 35 & 12 & 13 & 14 & 16 \\
\hline $\mathrm{V}$ & 180 & 200 & 259 & 224 & 47 & 86 & 95 & 76 \\
\hline $\mathrm{Cr}$ & 470 & 450 & 141 & 207 & 52 & 43 & 50 & 40 \\
\hline
\end{tabular}


Продолжени е та блицы 1

Continuation of Table 1

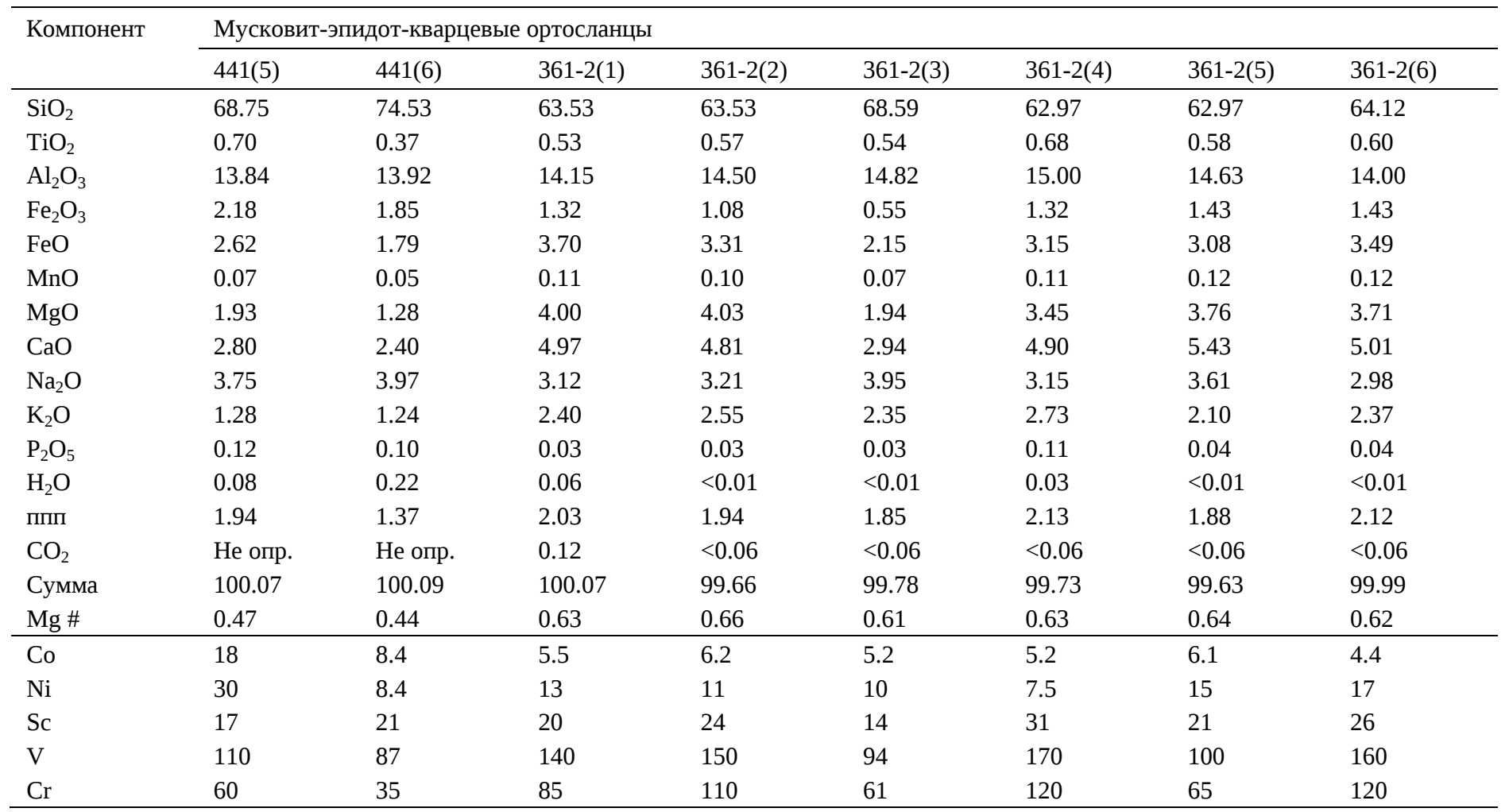

Продолжение та блицы 1

Continuation of Table 1

\begin{tabular}{|c|c|c|c|c|c|c|c|c|}
\hline \multirow[t]{2}{*}{ Компонент } & \multicolumn{8}{|c|}{ Мусковит-эпидот-кварцевые ортосланцы } \\
\hline & $361-3(1)$ & $361-3(2)$ & $361-3(3)$ & $361-3(4)$ & $361-3(5)$ & $361-3(6)$ & СКк 162-4 & СКк 162-6 \\
\hline $\mathrm{SiO}_{2}$ & 68.98 & 71.18 & 68.59 & 71.65 & 67.43 & 66.57 & 64.28 & 63.71 \\
\hline $\mathrm{Al}_{2} \mathrm{O}_{3}$ & 14.80 & 14.20 & 14.15 & 14.45 & 15.35 & 15.45 & 15.74 & 16.20 \\
\hline $\mathrm{Fe}_{2} \mathrm{O}_{3}$ & 2.33 & 2.24 & 2.74 & 1.63 & 2.51 & 2.87 & 1.14 & 1.87 \\
\hline $\mathrm{FeO}$ & 1.85 & 1.24 & 1.90 & 1.91 & 2.37 & 2.18 & 5.07 & 4.23 \\
\hline $\mathrm{MgO}$ & 1.23 & 0.68 & 1.64 & 1.07 & 1.62 & 1.19 & 2.94 & 2.84 \\
\hline $\mathrm{CaO}$ & 3.81 & 3.64 & 3.82 & 1.71 & 3.89 & 5.44 & 0.48 & 0.45 \\
\hline $\mathrm{Na}_{2} \mathrm{O}$ & 3.93 & 4.01 & 4.06 & 3.97 & 4.03 & 3.81 & 4.13 & 4.15 \\
\hline $\mathrm{K}_{2} \mathrm{O}$ & 1.08 & 1.07 & 0.66 & 1.44 & 0.72 & 0.53 & 2.00 & 2.38 \\
\hline $\mathrm{P}_{2} \mathrm{O}_{5}$ & 0.08 & 0.07 & 0.09 & 0.08 & 0.09 & 0.09 & 0.17 & 0.19 \\
\hline $\mathrm{H}_{2} \mathrm{O}$ & $<0.01$ & 0.06 & $<0.01$ & $<0.01$ & 0.04 & $<0.01$ & 0.07 & 0.09 \\
\hline $\mathrm{Mg} \#$ & 0.40 & 0.30 & 0.44 & 0.40 & 0.42 & 0.34 & 0.50 & 0.50 \\
\hline Co & 5.6 & 5.2 & 8.7 & 9.2 & 9 & 6 & 15 & 16 \\
\hline $\mathrm{Ni}$ & 22 & 11 & 16 & 12 & 20 & 19 & 33 & 38 \\
\hline Sc & 12 & 9.7 & 11 & 5.2 & 21 & 13 & 15 & 20 \\
\hline $\mathrm{V}$ & 44 & 41 & 53 & 23 & 110 & 65 & 135 & 165 \\
\hline $\mathrm{Cr}$ & 25 & 36 & 32 & 36 & 61 & 51 & 60 & 70 \\
\hline
\end{tabular}


О кон чание т а блицы 1

End of Table 1

\begin{tabular}{|c|c|c|c|}
\hline \multirow[t]{2}{*}{ Компонент } & \multicolumn{3}{|c|}{ Мусковит-эпидот-кварцевые ортосланцы } \\
\hline & скк $162-140$ & скк 162-145 & скк $162-147$ \\
\hline $\mathrm{SiO}_{2}$ & 62.40 & 61.10 & 67.84 \\
\hline $\mathrm{Al}_{2} \mathrm{O}_{3}$ & 14.18 & 15.67 & 13.91 \\
\hline $\mathrm{Fe}_{2} \mathrm{O}_{3}$ & 2.40 & 2.50 & 1.77 \\
\hline $\mathrm{FeO}$ & 3.47 & 3.84 & 2.34 \\
\hline $\mathrm{CaO}$ & 5.26 & 4.43 & 3.42 \\
\hline $\mathrm{Na}_{2} \mathrm{O}$ & 3.54 & 3.57 & 3.86 \\
\hline $\mathrm{K}_{2} \mathrm{O}$ & 1.29 & 1.55 & 2.09 \\
\hline $\mathrm{P}_{2} \mathrm{O}_{5}$ & 0.15 & 0.20 & 0.08 \\
\hline $\mathrm{H}_{2} \mathrm{O}$ & 0.09 & 0.09 & Не опр. \\
\hline $\mathrm{Mg} \#$ & 0.55 & 0.57 & 0.57 \\
\hline Co & 18 & 22 & 14 \\
\hline $\mathrm{Ni}$ & 43 & 53 & 37 \\
\hline Sc & 21 & 28 & 19 \\
\hline $\mathrm{V}$ & 167 & 134 & 132 \\
\hline $\mathrm{Cr}$ & 96 & 96 & 101 \\
\hline
\end{tabular}

пород мы используем серию диаграмм, основанных на содержании как петрогенных оксидов, так и редких элементов. На диаграмме $\left(\mathrm{Na}_{2} \mathrm{O}+\mathrm{K}_{2} \mathrm{O}\right)-\mathrm{SiO}_{2}$ ([Le Maitre, 1989], модифицированной согласно [Petrographic Code..., 2009], фигуративные точки всех проанализированных метавулканитов расположились в поле нормально- и низкощелочных пород, варьируясь по составу от базальтов до риодацитов (рис. 3, a). На диаграмме $\mathrm{MgO}-\left(\mathrm{FeO}^{*}+\mathrm{TiO}_{2}\right)-\mathrm{Al}_{2} \mathrm{O}_{3}$ [Jensen, 1976], которая используется для классификации метаморфизованных пород, точки составов метавулканитов образуют непрерывный ряд от высокомагнезиальных толеитовых базальтов через известково-щелочные базальты и андезиты к известково-щелочным дацитам (рис. 3, б). В связи с тем, что при построении диаграммы Л. Дженсона [Jensen, 1976] не используются элементы, которые могут быть мобильными при метаморфических преобразованиях $\left(\mathrm{SiO}_{2}, \mathrm{Na}_{2} \mathrm{O}, \mathrm{K}_{2} \mathrm{O}\right)$, серийная принадлежность пород, обоснованная с использованием данной диаграммы, является наиболее объективной. Для тех разностей метавулканитов, для которых были проанализированы содержания редких элементов, дополнительная классификация были проведена с использованием диаграммы $\mathrm{Zr} / \mathrm{TiO}_{2}-\mathrm{Nb} / \mathrm{Y}$ [Winchester, Floyd, 1977], как наиболее подходящей для анализа измененных пород. На этой диаграмме точки составов метавулканитов расположились в полях базальтов и андезитов (рис. 3, в). На основании обобщения всех отмеченных выше клас- сификаций можно сделать вывод о том, что проанализированные метавулканиты ушмуканской свиты принадлежат к базальт-андезит-дацитовой серии нормальной щелочности. Присутствие в разрезах дифференцированного ряда пород, вулканиты основного состава которого относятся как к толеитовой, так и к известково-щелочной серии, свидетельствует в пользу принадлежности данных пород к островодужной ассоциации.

Кварц-амфибол-эпидотовые, хлорит-амфибол-кварцэпидотовые, хлорит-серицит-кварцевые ортосланцы по своему химическому составу соответствуют нормальнощелочным высокомагнезиальным толеитовым базальтам, известково-щелочным базальтам и андезитам (рис. $3, a-8$ ), т.е. породам основного - среднего состава (далее для обозначения этих пород используется название «основные ортосланцы»). Эти породы представляют собой в разной степени дифференцированные разности, значения mg\# варьируются в них от 0.52 до 0.70 (табл. 1). Специфическими характеристиками данных ортосланцев являются низкие содержания $\mathrm{TiO}_{2}=0.19-0.83$ мас. \%, $\mathrm{FeO}^{*}=5.11-10.09$ мас. \%, $\mathrm{P}_{2} \mathrm{O}_{5}=0.03-0.24$ мас. \%. На вариационных диаграммах mg\# $-\mathrm{TiO}_{2}$, mg\# $-\mathrm{P}_{2} \mathrm{O}_{5}$ точки составов основных ортосланцев образуют единые отрицательные корреляционные тренды (рис. 4, $a$, б), а на диаграмме

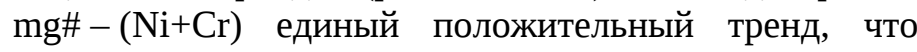
может свидетельствовать о формировании их в результате дифференциации одного источника (рис. 4, в). 
a
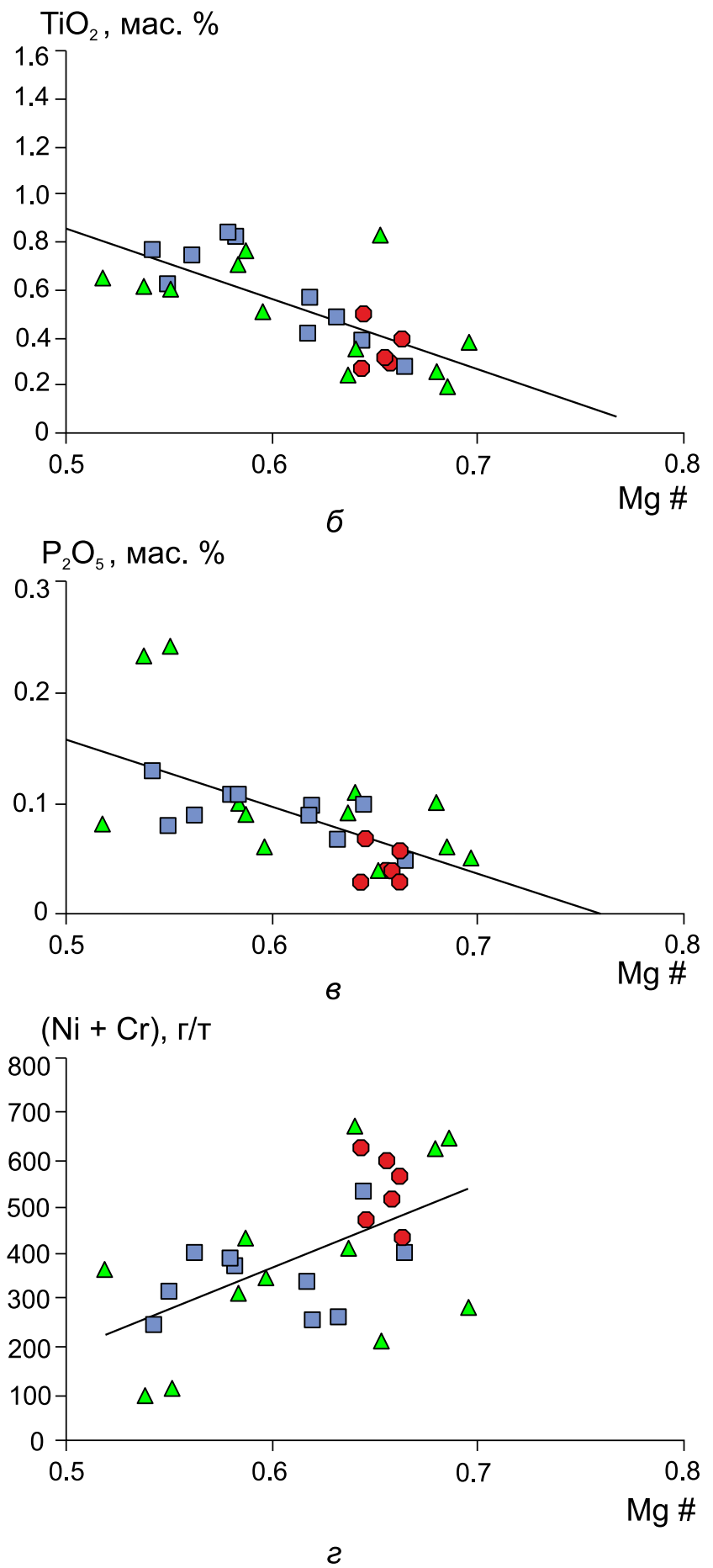

FeO*, мac. \%

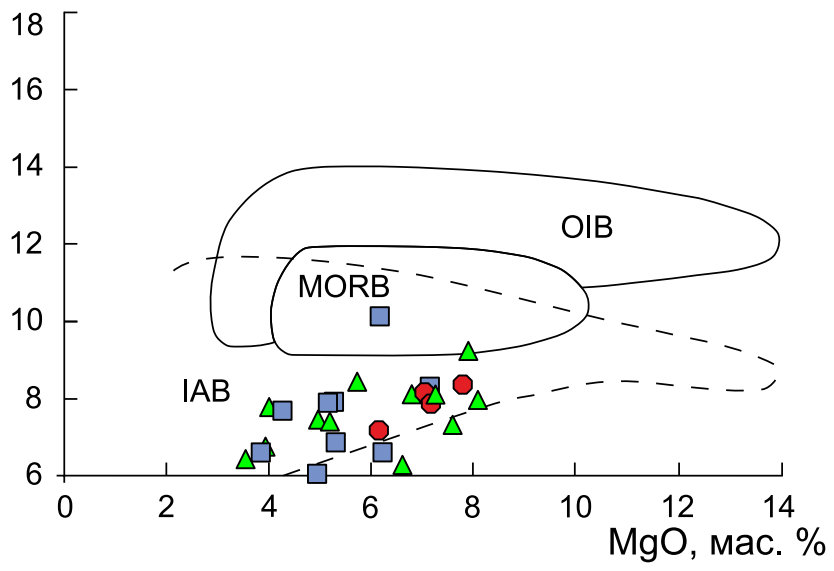

Рис 4. Диаграммы $\mathrm{TiO}_{2}-\mathrm{mg \#} \mathrm{(a),} \mathrm{P}_{2} \mathrm{O}_{5}-\mathrm{mg \#} \mathrm{(б),} \mathrm{Ni}+\mathrm{Cr}-\mathrm{mg \#}$ (в), FeO*-MgO [Turkina, Nozhkin, 2008] (2) для метаморфизованных вулканитов основного и среднего состава ушмуканской свиты.

Условные обозначения смотри на рис. 3. (2) ОІВ - базальты океанических островов; MORB - базальты срединно-океанических хребтов; IAВ - базальты островных дуг.

Fig. 4. Diagrams $\mathrm{TiO}_{2}-\mathrm{mg \#}(a), \mathrm{P}_{2} \mathrm{O}_{5}-\mathrm{mg \#}$ (б), $\mathrm{Ni}+\mathrm{Cr}-\mathrm{mg \#}$ (8), FeO*-MgO [Turkina, Nozhkin, 2008] (2) for metamorphosed volcanic rocks of basic and intermediate compositions of the Ushmukan suite.

See the legend in Figure 3. (2) OIB - oceanic-island basalt; MORB mid-ocean-ridge basalt; IAB - island-arc basalt. 
T а б л и ц а 2. Содержание редких и редкоземельных элементов в метаморфизованных вулканитах ушмуканской свиты

$\mathrm{T}$ a b l e 2. Contents of rare and rare-earth elements in metamorphosed volcanic rocks of the Ushmukan suite

\begin{tabular}{|c|c|c|c|c|c|c|c|c|c|}
\hline \multirow[t]{2}{*}{ Компонент } & \multicolumn{2}{|c|}{$\begin{array}{l}\text { Хлорит-серицит- } \\
\text { кварцевые ортосланцы }\end{array}$} & \multirow{2}{*}{$\begin{array}{l}\text { Кварц-амфибол- } \\
\text { эпидотовый орто- } \\
\text { сланец } \\
\text { с18-97(6) }\end{array}$} & \multicolumn{4}{|c|}{$\begin{array}{l}\text { Хлорит-амфибол-кварц-эпидотовые ортослан- } \\
\text { цы }\end{array}$} & \multicolumn{2}{|c|}{$\begin{array}{l}\text { Мусковит-эпидот- } \\
\text { кварцевые ортосланцы }\end{array}$} \\
\hline & c16-203(3) & $361-5(4)$ & & $361-1(1)$ & $361-4(6)$ & скк 161-1 & скк 161-2 & 441(3) & $441(6)$ \\
\hline $\mathrm{Rb}$ & 14.17 & 44.82 & 27.35 & 12.14 & 36.43 & 4.20 & 10.34 & 24.18 & 23.90 \\
\hline $\mathrm{Sr}$ & 204.54 & 138.00 & 155.99 & 643.01 & 204.12 & 264.08 & 167.48 & 230.34 & 241.99 \\
\hline $\mathrm{Y}$ & 11.57 & 21.49 & 8.52 & 17.04 & 9.93 & 17.40 & 12.73 & 24.64 & 21.56 \\
\hline $\mathrm{Zr}$ & 54.92 & 62.84 & 30.97 & 29.85 & 44.62 & 59.13 & 31.38 & 83.95 & 88.22 \\
\hline $\mathrm{La}$ & 3.36 & 6.99 & 2.20 & 2.58 & 5.35 & 2.85 & 3.69 & 9.24 & 10.43 \\
\hline $\mathrm{Ce}$ & 8.14 & 17.19 & 4.90 & 6.50 & 13.29 & 6.71 & 8.20 & 20.94 & 21.98 \\
\hline $\operatorname{Pr}$ & 1.14 & 2.27 & 0.67 & 0.97 & 1.55 & 0.95 & 1.12 & 2.54 & 2.80 \\
\hline $\mathrm{Nd}$ & 4.90 & 10.30 & 2.95 & 5.14 & 6.40 & 4.75 & 5.09 & 10.46 & 11.35 \\
\hline $\mathrm{Sm}$ & 1.47 & 2.91 & 0.86 & 1.76 & 1.86 & 1.52 & 1.48 & 2.71 & 2.76 \\
\hline $\mathrm{Eu}$ & 0.39 & 0.70 & 0.29 & 0.77 & 0.49 & 0.57 & 0.48 & 0.62 & 0.62 \\
\hline $\mathrm{Er}$ & 0.99 & 2.08 & 0.86 & 1.67 & 0.86 & 1.45 & 1.08 & 2.40 & 2.03 \\
\hline $\mathrm{Tm}$ & 0.15 & 0.32 & 0.15 & 0.27 & 0.13 & 0.23 & 0.16 & 0.39 & 0.32 \\
\hline $\mathrm{Yb}$ & 1.00 & 2.21 & 1.00 & 1.98 & 0.83 & 1.51 & 0.94 & 2.74 & 2.25 \\
\hline $\mathrm{Lu}$ & 0.18 & 0.39 & 0.18 & 0.37 & 0.15 & 1.51 & 0.94 & 0.54 & 0.42 \\
\hline $\mathrm{Hf}$ & 1.37 & 1.62 & 1.26 & 0.73 & 0.18 & 1.53 & 0.70 & 2.28 & 2.33 \\
\hline Th & 1.29 & 1.58 & 0.58 & 1.55 & 1.46 & 0.39 & 0.51 & 1.99 & 2.10 \\
\hline $\mathrm{U}$ & 0.77 & 0.72 & 0.94 & 0.68 & 0.64 & 0.11 & 0.14 & 0.85 & 0.49 \\
\hline $\mathrm{La} / \mathrm{Yb}_{n}$ & 2.25 & 2.12 & 1.46 & 0.87 & 4.31 & 1.26 & 2.31 & 2.25 & 3.10 \\
\hline $\mathrm{Nb} / \mathrm{La}_{\mathrm{Pm}}$ & 0.59 & 0.35 & 1.16 & 0.53 & 0.41 & 0.62 & 0.37 & 0.67 & 0.41 \\
\hline $\mathrm{Nb} / \mathrm{Th}_{\mathrm{Pm}}$ & 0.19 & 0.19 & 0.55 & 0.11 & 0.19 & 0.56 & 0.33 & 0.38 & 0.25 \\
\hline $\mathrm{Th} / \mathrm{La} a_{\mathrm{Pm}}$ & 3.11 & 1.83 & 2.12 & 4.85 & 2.21 & 1.10 & 1.12 & 1.74 & 1.62 \\
\hline $\mathrm{Eu} / \mathrm{Eu}^{*}$ & 0.78 & 0.77 & 1.00 & 1.28 & 0.82 & 1.01 & 0.98 & 0.71 & 0.68 \\
\hline
\end{tabular}

Низкие содержания $\mathrm{TiO}_{2}$, $\mathrm{FeO} *$ и умеренная магнезиальность в основных ортосланцах, положение точек составов ортосланцев на диаграмме $\mathrm{FeO} *-\mathrm{MgO}$ (рис. 4, 2) свидетельствуют в пользу их островодужной природы.

Проанализированные основные ортосланцы обнаруживают чрезвычайно низкие содержания $\mathrm{Nb}(1.42-$ 2.65 г/т) и редкоземельных элементов (сумма Р3Э= =16.6-52.4 г/т) (табл. 2), как ниже, так и немного выше, чем в базальтах N-MORB ( $\mathrm{Nb}=2.33$ г/т, P3Э=39.11 г/т [Sun, McDonough, 1989]). Низкие концентрации этих элементов являются отличительной чертой островодужных базальтов. Для основных ортосланцев характерно нефракционированное и слабофракционированное распределение редкоземельных элементов $\left(\mathrm{La} / \mathrm{Yb}_{\mathrm{n}}=0.87-4.31\right)$, а также слабовыраженные отрицательные и положительные Еu аномалии $\left(\mathrm{Eu} / \mathrm{Eu}^{*}=0.77-\right.$ 1.28) (рис. 5, a).
Основные ортосланцы характеризуются варьирующимися концентрациями крупноионных литофильных элементов $\quad(\mathrm{Rb}=4-45 \quad$ г/т, $\mathrm{Sr}=138-643 \quad$ г/т, $\mathrm{Ba}=73-$ 410 г/т) и, соответственно, невыдержанными аномалиями на мультиэлементных спектрах (рис. 5, б). Так как эти элементы являются мобильными в процессе метаморфических и метасоматических преобразований пород, содержания этих элементов не отражают состав источника пород.

За исключением одного образца, все остальные основные ортосланцы характеризуются значениями отношений $\mathrm{Nb} / \mathrm{La}_{\mathrm{pm}}<1 \quad(0.35-0.62)$ и $\mathrm{Nb} / \mathrm{Th}_{\mathrm{pm}}<1 \quad(0.11-$ 0.56) (табл. 2) и, соответственно, хорошо выраженной отрицательной $\mathrm{Nb}$ аномалией на мультиэлементных спектрах (Nb/Nb*=0.26-0.63) (рис. 5, б). Для одного образца кварц-амфибол-эпидотового ортосланца (№ c18-97(6)) отмечается значение $\mathrm{Nb} / \mathrm{La}_{\mathrm{pm}}>1$ (1.16), при этом $\mathrm{Nb} / \mathrm{Th}_{\mathrm{pm}}<1(0.55)$ и $\mathrm{Nb} / \mathrm{Nb}^{*}=0.85$ (рис. 5, б). 
О кончание та блицы 2

End of Table 2

Компонент Мусковит-эпидот-кварцевые ортосланцы

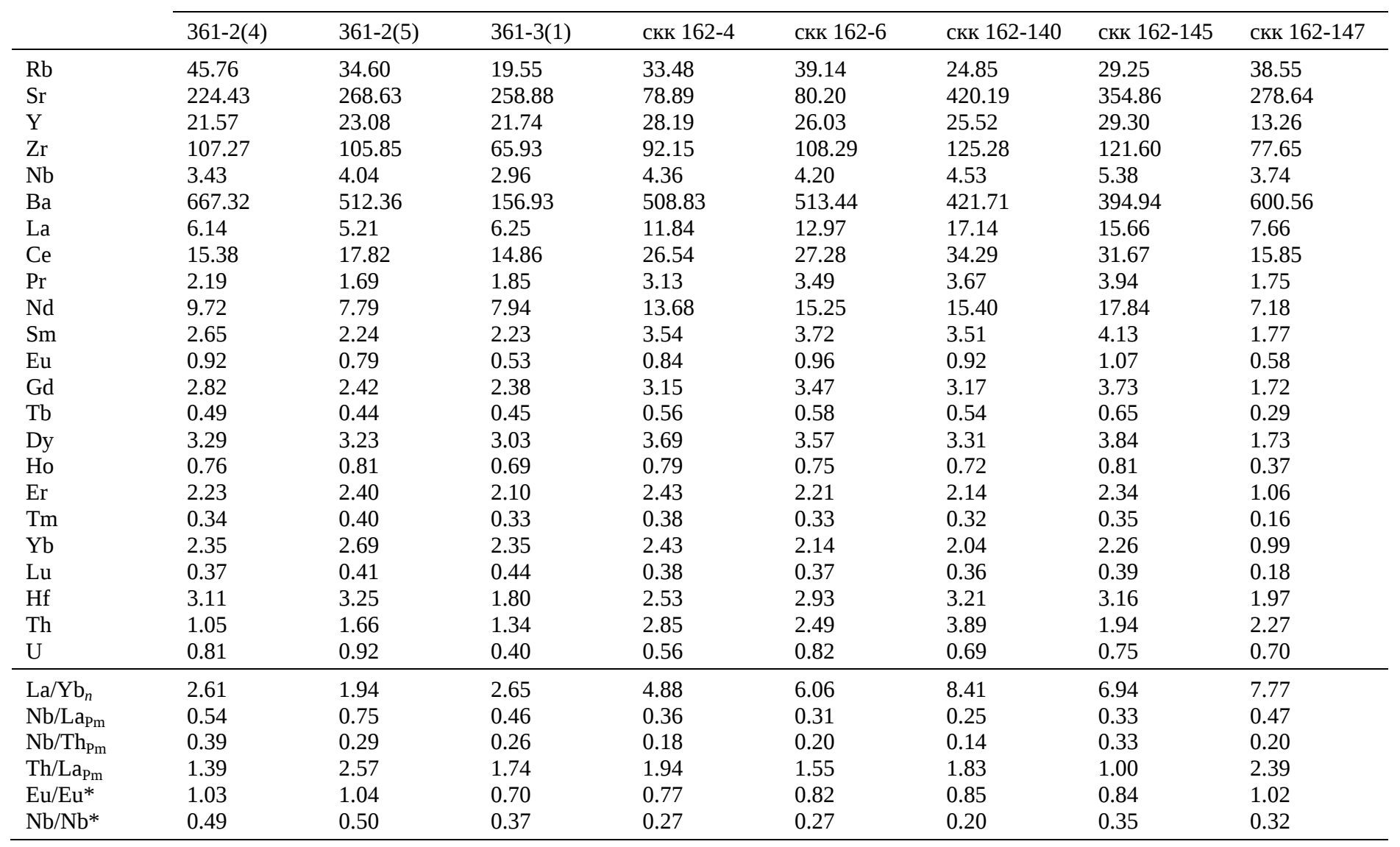

П р и м е ч а н и е. $\mathrm{Eu} / \mathrm{Eu}^{*}=\mathrm{Eu}_{\mathrm{n}} /\left(\sqrt{\left(\mathrm{Sm}_{\mathrm{n}} \times \mathrm{Gd}_{\mathrm{n}}\right)}\right) ; \mathrm{Nb} / \mathrm{Nb}^{*}=0.3618 * \mathrm{Nb} /(\sqrt{(\mathrm{Th} \times \mathrm{La})})$. n - значения нормализованы по составу хондрита [Nakamura, 1974], pm - значения нормализованы по составу примитивной мантии [Sun, McDonough, 1989].

$\mathrm{N}$ o t e. $\mathrm{Eu} / \mathrm{Eu}^{*}=\mathrm{Eu}_{\mathrm{n}} /\left(\sqrt{\left(\mathrm{Sm}_{\mathrm{n}} \times \mathrm{Gd}_{\mathrm{n}}\right)}\right) ; \mathrm{Nb} / \mathrm{Nb}^{*}=0.3618 * \mathrm{Nb} /(\sqrt{(\mathrm{Th} \times \mathrm{La})}) . \mathrm{n}-$ values normalized to the chondrite composition [Nakamura, 1974], pm - values normalized to the primitive mantle composition [Sun, McDonough, 1989].

Содержание Th в основных ортосланцах повышенное относительно базальтов типа N-MORB и составляет 0.39-1.58 г/т (табл. 2). Для всех проанализированных основных ортосланцев отмечается $\mathrm{Th} / \mathrm{La}_{\mathrm{pm}}>1$ (1.104.85) (табл. 2). Большинство проанализированных основных ортосланцев обнаруживают отрицательную аномалию по $\mathrm{Ti}$ на мультиэлементных спектрах ( $\left.\mathrm{Ti} / \mathrm{Ti}^{*}=0.33-0.82\right)$, только для одного образца отмечается отсутствие аномалии по $\mathrm{Ti}\left(\mathrm{Ti} / \mathrm{Ti}^{*}=1.12\right)$ (рис. 5 , б). Отрицательные Nb и Ti аномалии на мультиэлементых спектрах могут отражать как вклад субдукционного компонента в мантийный источник, так и контаминацию мантийного источника коровым материалом. Наличие в едином разрезе проанализированных основных ортосланцев образцов с $\mathrm{Nb} / \mathrm{La}_{\mathrm{pm}}>1$ и $\mathrm{Ti} / \mathrm{Ti} *>1$, т.е. с невыраженными отрицательными Nb и Ti аномалиями на мультиэлементных спектрах (рис. 5, б), а также образцов с $\mathrm{La} / \mathrm{Yb}_{\mathrm{n}}<1$ свидетельствует о том, что геохимические характеристики данных ортосланцев являются отражением составов их мантийных источников, а не связаны с ассимиляцией мантийным источником корового материала. Основные ортосланцы, для которых типична отрицательная $\mathrm{Nb}$ аномалия, обнаруживают относительно высокие значения $\mathrm{Ce} / \mathrm{Nb}$ (3.7-6.8) и Th/Nb (0.2-1.1), и на диаграмме $\mathrm{Ce} / \mathrm{Nb}$ $\mathrm{Th} / \mathrm{Nb}$ [Saunders et al., 1988] располагаются вблизи поля базальтов островных дуг, показывая, что в источнике этих основных ортосланцев присутствовал субдукционный компонент SDC (рис. 6, а). Образец кварцамфибол-эпидотового ортосланца (№ c18-97(6)) с $\mathrm{Nb} / \mathrm{La}_{\mathrm{pm}}>1$ обнаруживает более низкие значения $\mathrm{Ce} / \mathrm{Nb}$ и Th/Nb относительно как остальных основных ортосланцев, так и состава примитивной мантии (PM). В совокупности, на диаграмме $\mathrm{Ce} / \mathrm{Nb}-\mathrm{Th} / \mathrm{Nb}$ [Saunders et $a l ., 1988]$ большинство точек составов основных ортосланцев располагаются между точками SDC и $\mathrm{PM}$, что 

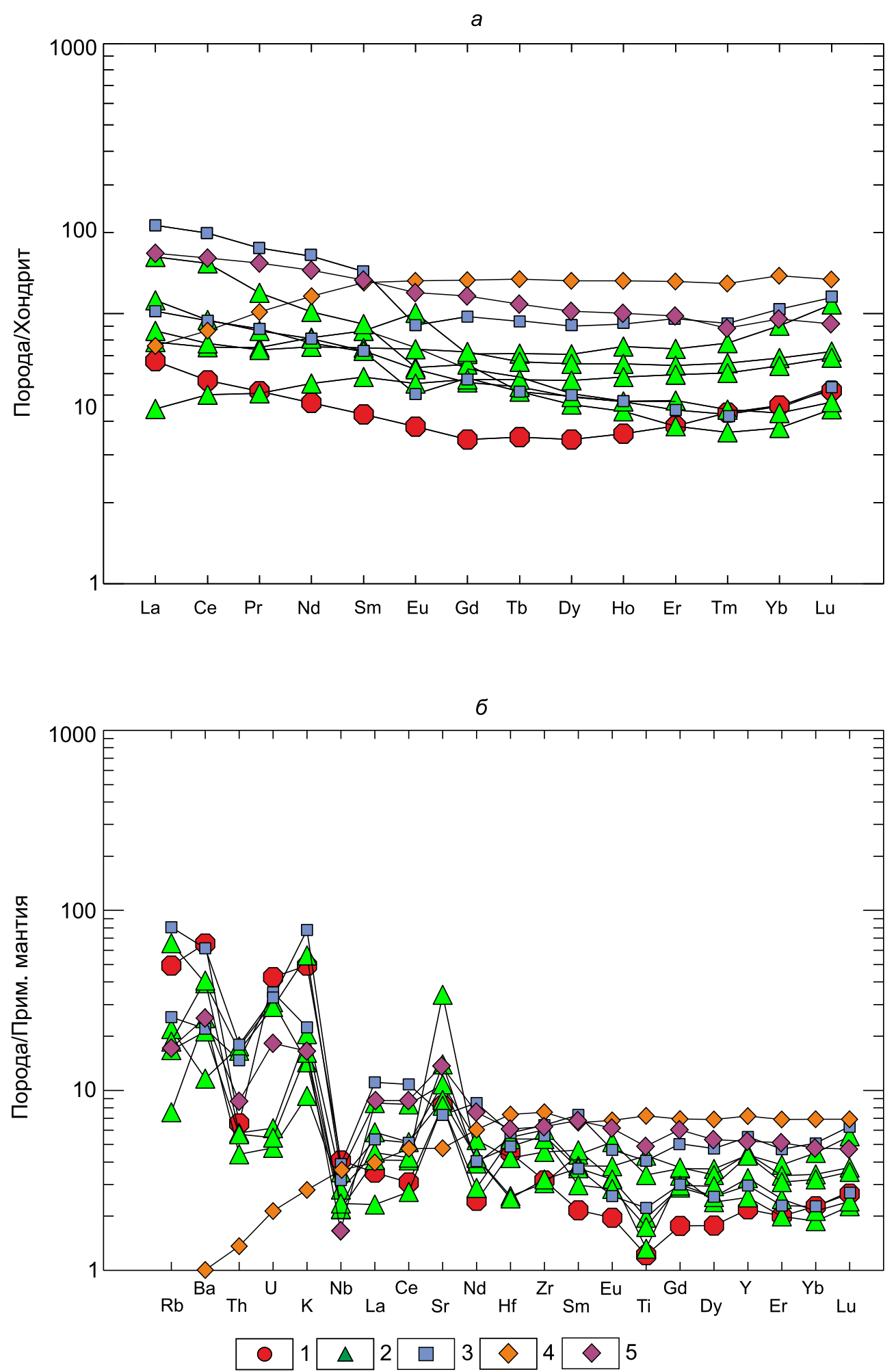

Рис. 5. Спектры распределения редкоземельных элементов, нормализованные к хондриту [Nakamura, 1974] (a), и мультиэлементные спектры, нормализованные к составу примитивной мантии [Sun, McDonough, 1989] (б), для метаморфизованных вулканитов основного и среднего состава ушмуканской свиты.

1 - кварц-амфибол-эпидотовые ортосланцы; 2 - хлорит-амфибол-кварц-эпидотовые ортосланцы; 3 - хлорит-серицит-кварцевые ортосланцы; 4 - базальты срединно-океанических хребтов [Sun, McDonough, 1989]; 5 - низкокалиевый базальт островной дуги [Ivanov et al., 2008].

Fig. 5. Chondrite-normalized [Nakamura, 1974] REE patterns (a), and primitive mantle-normalized [Sun, McDonough, 1989] multielement spectra (б) for metamorphosed volcanic rocks of basic and intermediate compositions of the Ushmukan suite.

1 - quartz-amphibole-epidote ortoschists, 2 - chlorite-amphibole-quartz-epidote ortoschists, 3 - chlorite-sericite-quartz ortoschists; 4 - mid-oceanridge basalt [Sun, McDonough, 1989]; 5 - low-K island-arc basalt [Ivanov et al., 2008]. 
a

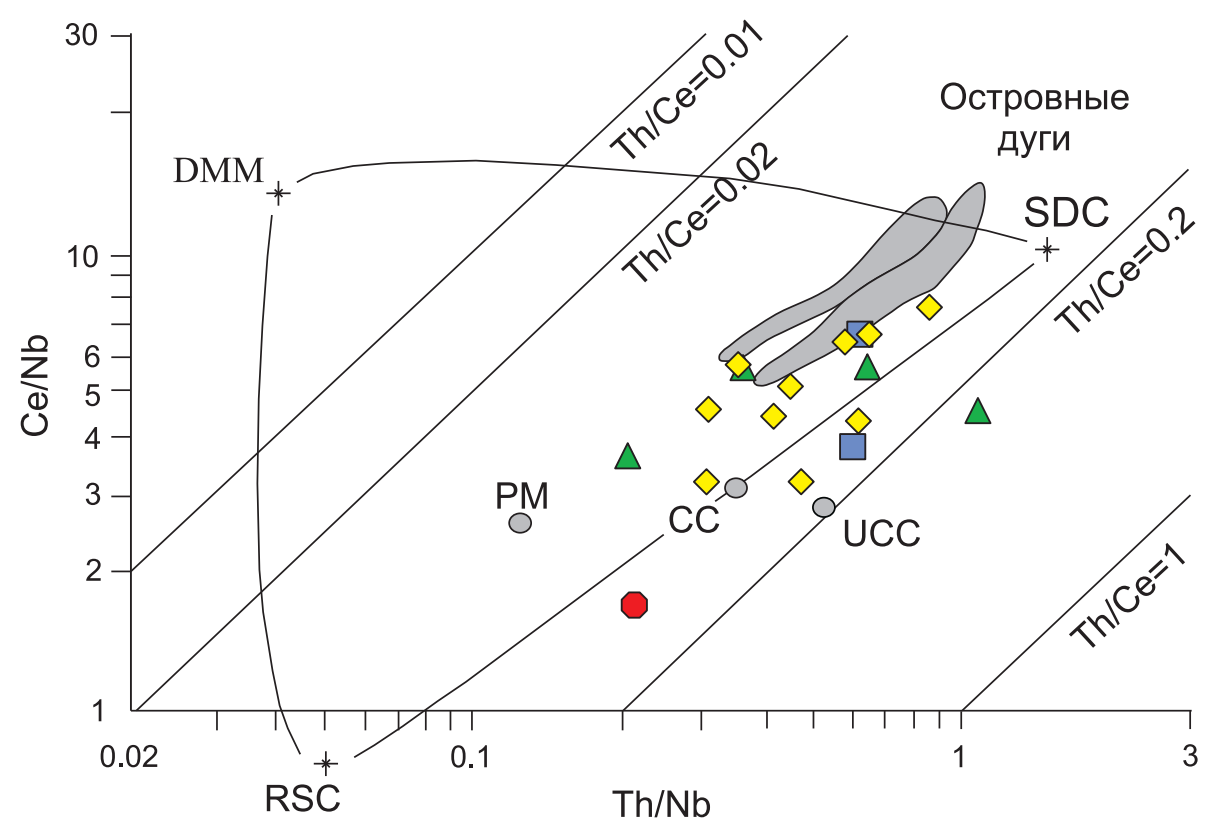

$\sigma$

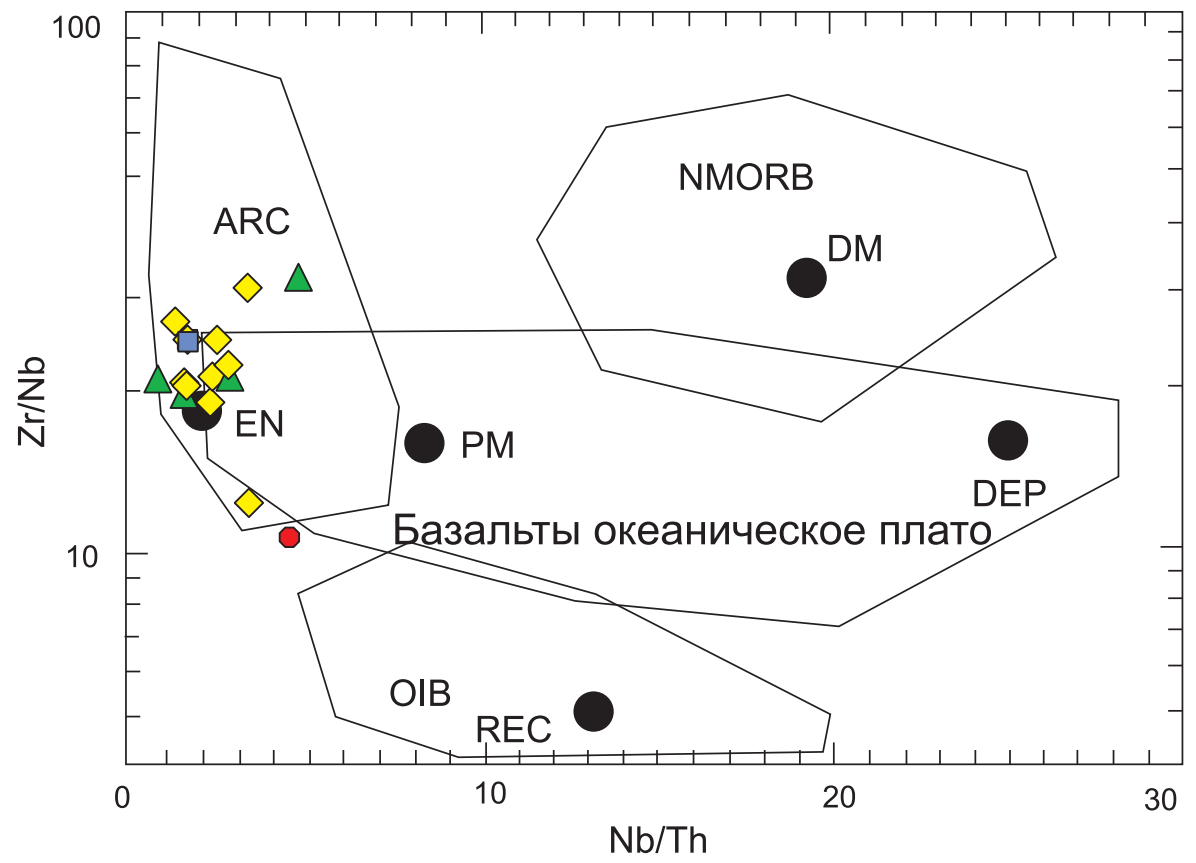

Рис 6. Диаграммы Ce/Nb-Th/Nb [Saunders et al., 1988] (a) и Zr/Nb-Nb/Th [Condie, 2005] (б) для метаморфизованных вулканитов ушмуканской свиты.

Условные обозначения смотри на рис. 3. (a) - DMM - деплетированная MORB мантия, RSC - остаточный компонент слэба, SDC - субдукционный компонент, CC - континентальная кора, UCC - верхняя континентальная кора. Линиями показаны траектории смешения между компонентами. Точки составов континентальной коры, верхней континентальной коры и поля базальтов островных дуг показаны по [Dampare et al., 2008]; (б) - поля: ARC - островодужные базальты, NMORB - базальты срединно-океанических хребтов, OIB - базальты океанических островов. Точки составов: DM - верхняя деплетированная мантия, DEP - глубинная деплетированная мантия, РМ примитивная мантия, REC - рециклированный компонент, EN - обогащенный компонент.

Fig. 6. Diagrams Ce/Nb-Th/Nb [Saunders et al., 1988] (a) and Zr/Nb-Nb/Th [Condie, 2005] (б) for metamorphosed volcanic rocks of the Ushmukan suite.

See the legend in Figure 3. (a) - DMM - depleted MORB mantle, RSC - residual slab component, SDC - subduction component, CC - continental crust, UCC - upper continental crust. Lines show the mixing trajectory between the components. Points of compositions of the continental crust, the upper continental crust and the island-arc basalt field are shown according to [Dampare et al., 2008]; (б) - fields: ARC - island-arc basalt, NMORB - mid-ocean ridge basalt, OIB - oceanic-island basalt. Composition points: DM - upper depleted mantle, DEP - deep depleted mantle, PM - primitive mantle, REC - recycled component, EN - enriched component. 
V.A. Vanin et al.: The Neoproterozoic island-arc association...

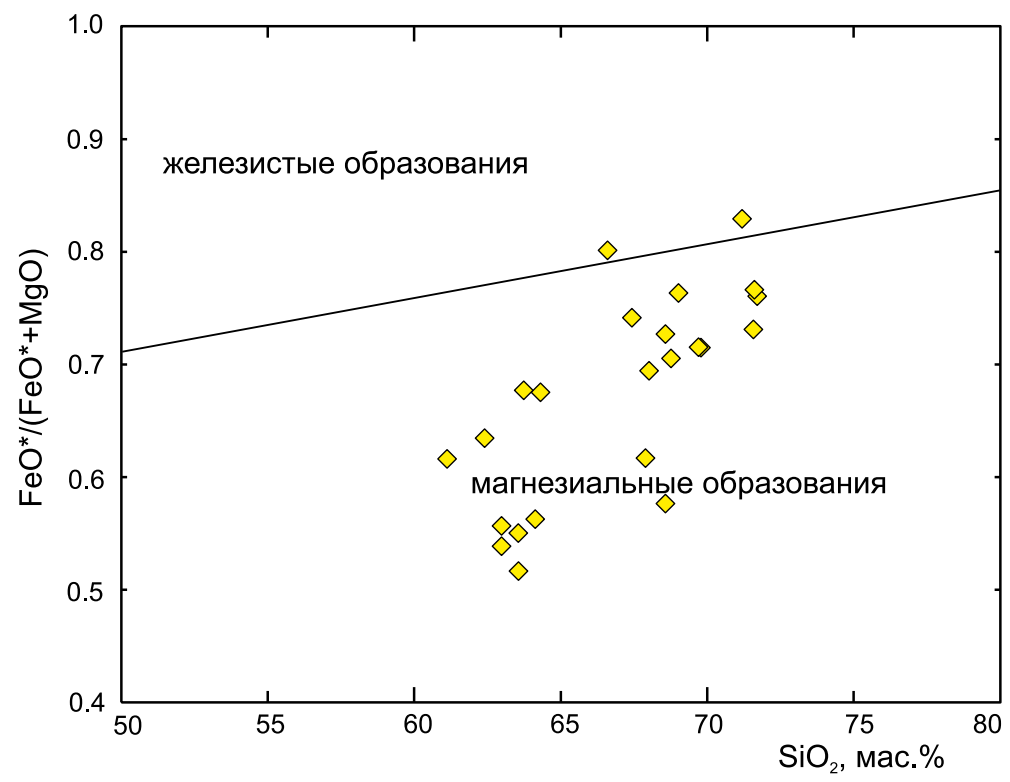

Рис 7. Классификационная диаграмма $\mathrm{FeO} *(\mathrm{FeO} *+\mathrm{MgO})-\mathrm{SiO}_{2}$ [Frost et al., 2001] для метаморфизованных вулканитов кислого состава ушмуканской свиты.

Fig. 7. Classification diagram $\mathrm{FeO}^{*} /(\mathrm{FeO} *+\mathrm{MgO})-\mathrm{SiO}_{2}$ [Frost et al., 2001] for metamorphosed felsic volcanic rocks of the Ushmukan suite.

может указывать на формирование этих ортосланцев в результате плавления мантийного источника, образованного за счет смешения примитивного мантийного и субдукционного компонентов (рис. 6, а). На диаграмме $\mathrm{Zr} / \mathrm{Nb}-\mathrm{Nb} / \mathrm{Th}$ [Condie, 2005] практически все точки составов проанализированных основных ортосланцев попадают в поле базальтов островных дуг (рис. 6, б).

Мусковит-эпидот-кварцевые ортосланцы по своему химическому составу соответствуют низко- и нормальнощелочным, известково-щелочным андезитам и дацитам (см. рис. 3, a-8) (далее для обозначения этих пород используется название «ортосланцы кислого состава»). Значения mg\# варьируются в подобных ортосланцах от 0.30 до 0.66 (см. табл. 1). На основании значений $f^{*}=\mathrm{FeO}^{*} /\left(\mathrm{FeO}^{*}+\mathrm{MgO}\right)$ проанализированные ортосланцы кислого состава относятся к магнезиальным образованиям (рис. 7). Характерными особенностями этих пород являются низкие содержания $\mathrm{Nb}$ (3.0-6.4 г/т) и редкоземельных элементов (сумма P3Э=41.3-88.7 г/т), только немного более высокие, чем в основных ортосланцах (табл. 2). Для ортосланцев кислого состава, так же как и для основных ортосланцев, характерно нефракционированное и слабофракционированное распределение редкоземельных элементов (La/Y $\left.\mathrm{Yb}_{\mathrm{n}}=1.30-5.63\right)$, а также слабовыраженные отрицательные $\mathrm{Eu}$ аномалии или ее отсутствие $\left(\mathrm{Eu} / \mathrm{Eu}^{*}=0.68-1.04\right)$ (рис. 8, a).

Все ортосланцы кислого состава обнаруживают значения отношений $\mathrm{Nb} / \mathrm{La}_{\mathrm{pm}}<1$ (0.25-0.75) и $\mathrm{Nb} / \mathrm{Th}_{\mathrm{pm}}<1$ (0.14-0.39) и, соответственно, хорошо выраженную от- рицательную $\mathrm{Nb}$ аномалию на мультиэлементных спектрах (Nb/Nb*=0.20-0.54) (рис. 8, б). Также ортосланцы кислого состава характеризуются отрицательной аномалией по Ті на мультиэлементных спектрах (Ti/Ti*= $=0.31-0.59)$.

Проанализированные ортосланцы кислого состава имеют концентрации Тh либо близкие к основным ортосланцам, либо немного выше (1.05-3.89 г/т против 0.39-1.58 г/т), при этом отношения $\mathrm{Th} / \mathrm{Nb}_{\mathrm{pm}}$ в тех и других породах полностью перекрываются (2.6-7.2 против 1.8-9.1) (табл. 2). Такой же вывод можно сделать и при сопоставлении содержаний La и отношений $\mathrm{Th} / \mathrm{La}_{\mathrm{pm}}$ в ортосланцах кислого и основного состава (табл. 2). На диаграммах $\mathrm{Ce} / \mathrm{Nb}$ - Th/Nb [Saunders et al., 1988] и $\mathrm{Zr} / \mathrm{Nb}$ - Nb/Th [Condie, 2005] точки составов кислых ортосланцев попадают в те же поля, что и фигуративные точки основных ортосланцев (см. рис. $6, a$, б). Таким образом, близкие значения отношений несовместимых элементов в основных и кислых ортосланцах могут свидетельствовать о формировании этих пород из единого субдукционно-обогащенного источника. Более высокие содержания Th, La, Nb в большинстве ортосланцев кислого состава по отношению к основным ортосланцам связаны, по всей видимости, с процессами дифференциации этого источника. Хорошо выраженные Nb отрицательные аномалии на мультиэлементных спектрах ортосланцев кислого состава также являются унаследованными от этого источника субдукционного происхождения. Магнезиальный состав кислых ортосланцев свидетельствует о высокой активности $\mathrm{H}_{2} \mathrm{O}$ при их формировании, что 

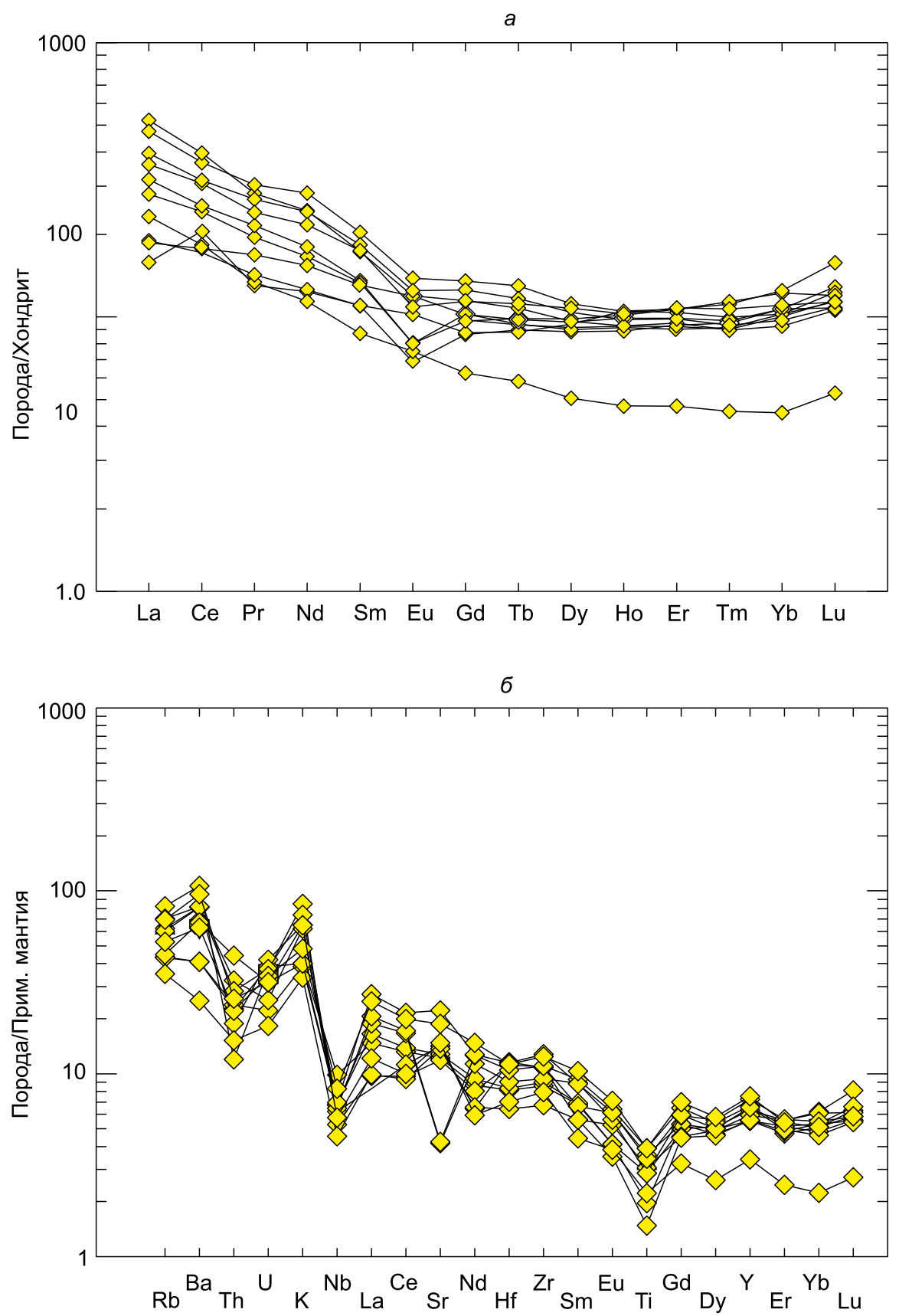

Рис. 8. Спектры распределения редкоземельных элементов, нормализованные к хондриту [Nakamura, 1974] (a), и мультиэлементные спектры, нормализованные к составу примитивной мантии [Sun, McDonough, 1989] (б), для метаморфизованных вулканитов кислого состава ушмуканской свиты.

Fig. 8. Chondrite-normalized [Nakamura, 1974] REE patterns (a), and primitive mantle-normalized [Sun, McDonough, 1989] multielement spectra (б) for metamorphosed felsic volcanic rocks of the Ushmukan suite.

является типичной характеристикой вулканитов кислого состава и гранитоидов, формирующихся в субдукционных обстановках. Специфической характеристикой проанализированных кислых ортосланцев являются повышенные содержания Y (13-29 г/т) и $\mathrm{Yb}$ (0.99-2.74 г/т), что свидетельствует о том, что формирование данных пород происходило при невысоких давлениях в отсутствие граната в рестите.

Таким образом, обобщая изложенные выше данные по геохимии ортосланцев ушмуканской свиты, можно сделать вывод об островодужной природе данных первично-вулканогенных образований и о их формировании в надсубдукционной геодинамической обстановке.

Применительно к рассмотрению вещественного состава и геодинамической интерпретации условий образования метавулканитов ушмуканской свиты необходимо отдельно остановиться на возможной роли 
этих пород как вероятного поставщика ювенильного золота в верхние горизонты земной коры. Как известно, в породах островодужной ассоциации отмечаются существенно повышенные относительно кларковых содержания золота (обзор в [Bogatikov, 1987; Yarmolyuk, Kovalenko, 1991]). Стоит отметить, что в пределах рудного поля Мукодек промышленные содержания золота зафиксированы лишь в березит-лиственитовых метасоматитах золото-кварц-сульфидной формации, образованных по метавулканитам ушмуканской свиты. Содержания золота в этих метасоматитах достигают 20-36 г/т, а порой и 70 г/т. В то же время содержания золота в метасоматитах, развивающихся по габброидам и гранитоидам муйского комплекса, не превышают 0.8 г/т и 2.0 г/т, соответственно. Однако для гранитоидов, даже несмотря на относительно повышенные по сравнению с кларком концентрации золота, не представляется возможным выделить рудные тела, соответствующие кондиционным параметрам. Принимая во внимание отмеченную особенность локализации золота на изученной территории, можно предположить, что именно метавулканиты ушмуканской свиты, имеющие отчетливую островодужную специфику, могли явиться источником золота для рудных объектов золоторудного поля Мукодек.

\section{5. ЗАКЛЮЧЕНИЕ}

Проведенные исследования геологического строения разрезов, а также минерального и вещественного состава метавулканитов ушмуканской свиты золоторудного поля Мукодек, располагающегося в пределах Байкало-Муйского пояса ЦАСП, позволили установить, что субстратом изученных пород явились породы базальт-андезит-дацитовой серии, обладающие геохимическими характеристиками, типичными для надсубдукционных образований. Комплекс полученных результатов позволяет отнести исследованные метавулканиты к породам островодужной ассоциации, которая может рассматриваться в качестве вещественно- го и возрастного аналога широко известной в регионе келянской свиты позднего рифея (неопротерозоя) [Tsygankov, 2005]. При этом присутствие в изученных разрезах ушмуканской свиты метавулканитов среднего и кислого состава указывает на то, что образование данных пород имело место в пределах развитой острово-

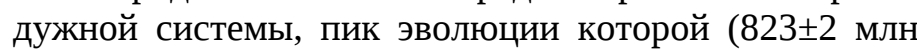
лет) [Rytsk et al., 2001] фиксируется плагиориолитами келянской свиты.

Новые данные свидетельствуют о более масштабном, чем это предполагалось ранее [Tsygankov, 2005], развитии на площади Байкало-Муйского пояса пород островодужной специфики, отражающих процессы трансформации примитивной коры Палеоазиатского океана в более зрелую литосферу переходного (островодужного) типа. Примечательно, что подобные надсубдукционные процессы субсинхронно проявились и в Восточно-Саянском сегменте ЦАСП (обзор в [Kuz'michev, 2004]), отражая глобальный процесс закрытия бассейнов, отделявших систему позднерифейских островных дуг от южного фланга Сибирского кратона.

Помимо определенной важности полученных результатов для воссоздания целостного сценария эволюции Байкало-Муйского пояса, принципиальным приложением доказанной островодужной природы метавулканитов ушмуканской свиты является возможность их рассмотрения в качестве источника ювенильного золота, которое в настоящее время локализовано в березит-лиственитовых метасоматитах золото-кварцсульфидной формации. По-видимому, островодужные, изначально обладающие повышенными содержаниями золота позднерифейские вулканиты ушмуканской свиты могли явиться поставщиком этого рудного компонента в верхние горизонты коры. В последующем, в результате реализации нескольких этапов тектонотермальной переработки пород [Vanin, Gladkochub, 2014], первоначально рассеянное в вулканитах золото было сконцентрировано в рудных телах, совокупность которых образует изученное золоторудное поле Мукодек.

\section{6. ЛИTEPATУРA / REFERENCES}

Artemiev A.N., Tsypukov Yu.P., 1963. Report on geological survey works conducted by Orkolikan Party in 1962. Irkutsk (in Russian) [Артемьев А.Н., Цыпуков Ю.П. Отчет о геологосъемочных работах, проведенных Орколиканской партией в 1962 г. Иркутск, 1963].

Belichenko V.G., Butov Yu.P., Boos R.G., Vratkovskaya S.V., Dobretsov N.L., Dolmatov V.A., Zhmodik S.M., Konnikov E.G., Kuz'min M.I., Medvedev V.N., Melanina N.M., Mironov A.G., Nemirovskaya N.A., Ogurtsov A.M., Postnikov A.A., Roschektaev P.A., Sklyarov E.V., Filimonov A.V., Shafeev AA., 1988. Geology and Metamorphism of Eastern Sayan. Nauka, Novosibirsk, 192 p. (in Russian) [Беличенко В.Г., Бутов Ю.П., Боос Р.Г., Вратковская С.В., Добрецов Н.Л., Долматов В.А., Жмодик С.М., Конников Э.Г., Кузьмин М.И., Медведев В.Н., Меланина Н.М., Миронов А.Г., Немировская Н.А., Огурцов А.М., Постников А.А., Рощектаев П.А., Скляров Е.В., Филимонов А.В., Шафеев А.А. Геология и метаморфизм Восточного Саяна. Новосибирск: Наука, 1988. 192 с.].

Bogatikov O.A., 1987. Petrology and Geochemistry of Island Arcs and Marginal Seas. Nauka, Moscow, 335 p. (in Russian) [Богатиков О.А. Петрология и геохимия островных дуг и окраинных морей. М.: Наука, 1987. 335 с.]. 
Condie K.C., 2005. High field strength element ratios in Archean basalts: a window to evolving sources of mantle plumes? Lithos 79 (3-4), 491-504. http://dx.doi.org/10.1016/j.lithos.2004.09.014.

Dampare S.B., Shibata T., Asiedu D.K., Osae S, Banoeng-Yakubo B, 2008. Geochemistry of Paleoproterozoic metavolcanic rocks from the southern Ashanti volcanic belt, Ghana: Petrogenetic and tectonic setting implications. Precambrian Research 162 (3-4), 403-423. http://dx.doi.org/10.1016/j.precamres.2007.10.001.

Dobretsov N.L., 1983. Ophiolites and problems of the Baikal-Muya ophiolite belt. In: Magmatism and metamorphism of the BAM zone and their role in the formation of minerals. Nauka, Novosibirsk, p. 11-19 (in Russian) [Добрецов Н.Л. Офиолиты и проблемы Байкало-Муйского офиолитового пояса // Магматизм и метаморфизм зоны БАМ и их роль в формировании полезных ископаемых. Новосибирск: Наука, 1983. С. 11-19].

Dobretsov N.L., Belichenko V.G., Boos R.G., Butov Yu.P., Gordienko I.V., Zhmodik S.M., Ignatovitch V.I., Konstantinova K.K., Kotkin V.V., Kulikov Yu.I., Lyuchkin V.A., Mityukhin E.N., Nemchinov V.G., Osokin P.V., Postnikov A.A., Rasskazov S.V., Roschektaev P.A., Sizykh N.V., Sklyarov E.V., Skopintsev V.G., Shulyak G.B., 1989. Geology and Ore Potential of Eastern Sayan. Nauka, Novosibirsk, 126 p. (in Russian) [Добрецов Н.Л., Беличенко В.Г., Боос Р.Г., Бутов Ю.П., Гордиенко И.В., Жмодик С.М., Игнатович В.И., Константинова К.К., Коткин В.В., Куликов Ю.И., Лючкин В.А., Митюхин Е.Н., Немчинов В.Г., Осокин П.В., Постников А.А., Рассказов С.В., Рощектаев П.А., Сизых Н.В., Скляров Е.В., Скопинцев В.Г., Шуляк Г.Б. Геология и рудоносность Восточного Саяна. Новосибирск: Наука, 1989. 126 c.].

Dobretsov N.L., Ponomarev V.G., Kovalev K.R., 1985. The geological evolution and specific metallogenic features of the Olokit trough structure, Baikal mountain area. In: The Precambrian Trough structures of the Baikal-Amur region and their metallogeny. Proceedings of the Meeting. Novosibirsk, 53-67 (in Russian) [Добрецов Н.Л., Пономарев В.Г., Ковалев К.P. Геологическое развитие и особенности металлогении Олокитской троговой структуры (Байкальская горная область) // Докембрийские троговые структуры Байкало-Амурского региона и их металлогения: Материалы совещания. Новосибирск, 1985. С. 53-67].

Frost B.R., Barnes C.G., Collins W.J., Arculus R.J., Ellis D.J., Frost C.D., 2001. A geochemical classification for granitic rocks. Journal of Petrology 42 (11), 2033-2048. http://dx.doi.org/10.1093/petrology/42.11.2033.

Ivanov A.V., Perepelov A.B., Palesskii S.V., Nikolaeva I.V., 2008. First data on the distribution of platinum group elements (Ir, Os, Ru, Pt, and Pd) and Re in island-arc basalts of Kamchatka. Doklady Earth Sciences 420 (1), 597-601. http://dx. doi.org/10.1134/S1028334X08040168.

Jensen L.S., 1976. A New Cation Plot for Classifying Subalkalic Volcanic Rocks. Miscellaneous, Ontario Department of Mines. Paper 66. 22 p.

Konnikov E.G., Gibsher A.S., Izokh A.E., Sklyarov E.V., Khain E.V., 1994. The Late Proterozoic evolution of the northern segment of the Paleo-Asian Ocean: new radiological, geological and geochemical data. Geologiya i Geofizika (Russian Geology and Geophysics) 35 (7-8), 152-168 (in Russian) [Конников Э.Г., Гибшер А.С., Изох А.Э., Скляров Е.В., Хаин E.B. Позднепротерозойская эволюция северного сегмента Палеоазиатского океана: новые радиологические, геологические и геохимические данные // Геология и геофизика. 1994. Т. 35. № 7-8. С. 152-168].

Kuz'michev A.B., 2004. The Tectonic History of the Tuva-Mongolian Massif: Early Baikalian, Late Baikalian and Caledonian Stages. PROBEL-2000, Moscow, 192 p. (in Russian) [Кузьмичев А.Б. Тектоническая история Тувино-Монгольского массива: раннебайкальский, позднебайкальский и каледонский этапы. М.: ПРОБЕЛ-2000, 2004. 192 с.].

Le Maitre R.W., 1989. A Classification of Igneous Rocks and Glossary of Terms: Recommendations of the International Union of Geological Sciences Subcommission on the Systematics of Igneous Rocks. Blackwell, Oxford, 193 p.

Nakamura N., 1974. Determination of REE, Ba, Fe, Mg, Na and K in carbonaceous and ordinary chondrities. Geochimica et Cosmochimica Acta 38 (5), 757-775. http://dx.doi.org/10.1016/0016-7037(74)90149-5.

Panteeva S.V., Gladkochoub D.P., Donskaya T.V., Markova V.V., Sandimirova G.P., 2003. Determination of 24 trace elements in felsic rocks by inductively coupled plasma mass spectrometry after lithium metaborate fusion. Spectrochimica Acta. Part B: Atomic Spectroscopy 58 (2), 341-350. http://dx.doi.org/10.1016/S0584-8547(02)00151-9.

Peive A.V., 1969. The oceanic crust of the geological past. Geotektonika (Geotectonics) (4), 5-23 (in Russian) [Пейве A.B. Океаническая кора геологического прошлого // Геотектоника. 1969. № 4. С. 5-23].

Petrographic Code of Russia, 2009. Igneous, Metamorphic, Metasomatic and Impact Formations. VSEGEI, St. Petersburg, 200 p. (in Russian) [Петрографический кодекс России. Магматические, метаморфические, метасоматические, импактные образования. СПб.: ВСЕГЕИ, 2009. 200 с.].

Rozhok S.N., 1995. The Geological Structure and Minerals of the Mama River’s Right Bank and Yana and Gorbylyak River Basins. Report of Monyukan Party on Geological Exploration, Scale 1:50,000 and General Prospecting from 1989 to 1992. Irkutsk (in Russian) [Рожок С.Н. Геологическое строение и полезные ископаемые правобережья р. Правой Мамы, бассейнов рек Яны, Горбыляка. Отчет Монюканской партии по геологическому доизучению м-ба 1:50000 с общими поисками за 1989-1992 гг. Иркутск, 1995].

Rytsk E.Y., Amelin Y.V., Rizvanova N.G., Krymsky R S., Mitrofanov G.L., Mitrofanova N.N., Perelyaev V.I. Shalaev B.C., 2001. Age of rocks in the Baikal-Muya fold belt. Stratigraphy and Geological Correlation 9 (4), 315-326.

Rytsk E.Yu., Kovach V.P, Kovalenko V.I., Yarmolyuk V.V., 2007. Structure and Evolution of the Continental Crust in the Baikal Fold Region. Geotectonics 41 (6), 440-464. http://dx.doi.org/10.1134/S0016852107060027. 
Saunders A.D., Norry M.J., Tarney J., 1988. Origin of MORB and chemically depleted mantle reservoirs: trace element constraints. Journal of Petrology (Special Lithosphere Issue), 415-445. http://dx.doi.org/10.1093/petrology/Special_Volume. 1.415 .

Sun S., McDonough W.F., 1989. Chemical and isotopic systematics of oceanic basalts: implications for mantle composition and processes In: A.D. Saunders, M.J. Norry (Eds.), Magmatism in the oceanic basins. Geological Society, London, Special Publication 42, 313-345. http://dx.doi.org/10.1144/GSL.SP.1989.042.01.19.

Tsygankov A.A., 2005. Magmatic Evolution of the Baikal Muya Volcanoplutonic Belt in Late Precambrian. Publishing House of SB RAS, Novosibirsk, 306 p. (in Russian) [Цыганков А.А. Магматическая эволюция Байкало-Муйского вулканоплутонического пояса в позднем докембрии. Новосибирск: Издательство СО РАН, 2005. 306 с.].

Turkina O.M., Nozhkin A.D., 2008. Oceanic and riftogenic metavolcanic associations of greenstone belts in the northwestern part of the Sharyzhalgai Uplift, Baikal region. Petrology 16 (5), 468-491. http://dx.doi.org/10.1134/S0869591108050044.

Vanin V.A., Gladkochub D.P., 2014. Geology and stages of the Mukodek gold-ore field, Northern Pribaikalie. Geology and Mineral Resources of Siberia (in press) (in Russian) [Ванин В.А., Гладкочуб Д.П. Геология и этапы формирования золоторудного поля Мукодек (Северное-Прибайкалье) // Геология и минерально-сырьевые ресурсы Сибири. 2014 (в печати)].

Winchester J.A., Floyd P.A., 1977. Geochemical discrimination of different magma series and their differentiation products using immobile elements. Chemical Geology 20, 325-343. http://dx.doi.org/10.1016/0009-2541(77)90057-2.

Yarmolyuk V.V., Kovalenko V.I., 1991. Rift Magmatism of Active Continental Margins and Its Ore Potential. Nauka, Moscow, 262 p. (in Russian) [Ярмолюк В.В., Коваленко В.И. Рифтогенный магматизм активных континентальных окраин и его рудоносность. М.: Наука, 1991. 262 с.].

Zonenshain L.P., Kuzmin M.I., Natapov L.S., 1990. Plate Tectonics of the USSR Territory. Nedra, Moscow, V. 1, 327 p. (in Russian) [Зоненшайн Л.П., Кузьмин М.И., Натапов Л.Ш. Тектоника литосферных плит территории СССР. М.: Недра, 1990. Кн. 1. 327 с.].

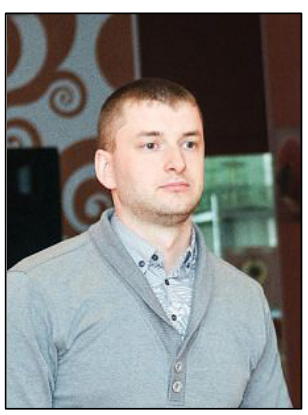

Ванин Вадим Александрович, аспирант

Институт земной коры СО РАН

664033, Иркутск, ул. Лермонтова, 128, Россия

Тел.: (3952)427117; факс: (3952)427000; $\$ e-mail: balagan-2000@mail.ru

Vanin, Vadim A., post graduate student

Institute of the Earth's crust of SB RAS

128 Lermontov street, Irkutsk 664033, Russia

Tel.: (3952)427117; fax: (3952)427000; $₫$ e-mail: balagan-2000@mail.ru

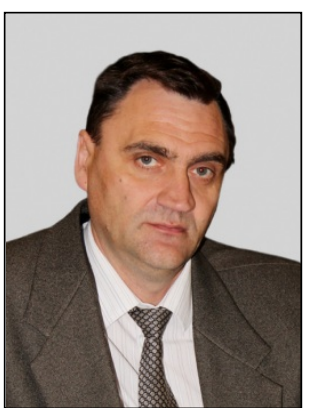

Гладкочуб Дмитрий Петрович, докт. геол.-мин. наук, директор института

Институт земной коры СО РАН

664033, Иркутск, ул. Лермонтова, 128, Россия

e-mail: dima@crust.irk.ru

Gladkochub, Dmitry P., Doctor of Geology and Mineralogy, Director of the Institute Institute of the Earth's Crust, Siberian Branch of RAS

128 Lermontov street, Irkutsk 664033, Russia

e-mail: dima@crust.irk.ru

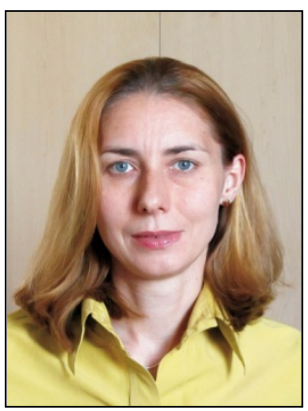

Донская Татьяна Владимировна, канд. геол.-мин. наук, с.н.с.

Институт земной коры СО РАН

664033, Иркутск, ул. Лермонтова, 128, Россия

e-mail: tanlen@crust.irk.ru

Donskaya, Tatiana V., Candidate of Geology and Mineralogy, Senior researcher

Institute of the Earth's Crust, Siberian Branch of RAS

128 Lermontov street, Irkutsk 664033, Russia

e-mail: tanlen@crust.irk.ru 